\title{
20. VEIN FORMATION MECHANISMS IN THE SHEETED DIKE COMPLEX FROM HOLE 504B ${ }^{1}$
}

\author{
Paola Tartarotti, ${ }^{2}$ Simon A. Allerton, ${ }^{3}$ and Christine Laverne ${ }^{4}$
}

\begin{abstract}
Diabases were recovered during Legs 137 and 140 at Hole 504B from depths between 1621.5 and 2000.4 meters below seafloor in the lower sheeted dike complex. The samples contain multiple generations of millimetric to centimetric veins. The orientation of the measured veins suggests that two main vein sets exist: one characterized by shallow dipping and the other by random trend. Thermal contraction during rock cooling is considered the main mechanism responsible for fracture formation. Vein infill is related to the circulation of hydrothermal fluids near the spreading axis. Some veins are surrounded by millimeter-sized alteration halos due to fluid percolation from the fractures through the host rock. Vein-filling minerals are essentially amphibole, chlorite, and zeolites. Amphibole composition is controlled by the microstructural site of the rock. Actinolite is the main amphibole occurring in the veins and also in the groundmass away from the halos. In the alteration halos, amphibole shows composition of actinolitic hornblende and $\mathrm{Mg}$-hornblende. Late-stage tension gashes and interstitial spaces in some amphibole-bearing veins are filled with zeolites, suggesting that the veins likely suffered multiple opening stages that record the cooling history of the circulating fluids. Evidence of deformation recorded by the recovered samples seems to be restricted to veins that clearly represent elements of weakness of the rock. On the basis of vein geometry and microstructure we infer structural interpretations for the formation mechanism and for deformation of veins.
\end{abstract}

\section{INTRODUCTION}

Diabases were recovered during Legs 137 and 140 at Hole 504B from a section of the sheeted dike complex that extends between 1562.3 meters below seafloor (mbsf; i.e., 1287.8 meters sub-basement) and 2000.4 mbsf (1725.9 meters sub-basement; Fig. 1). These rocks are crosscut by abundant millimetric to centimetric veins. Veins are ubiquitous downhole, but their distribution appears heterogeneous. Five main categories of veins may be distinguished on the basis of their mineral fills: (1) chlorite-bearing veins; (2) amphibole-bearing veins; (3) chlorite + amphibole-bearing veins; (4) chlorite + pyrite-bearing veins; and (5) epidote + quartz-bearing veins. There are no consistent crosscutting relationships among these vein generations. In all cases, however, the epidote + quartz-bearing veins appear to be the latest veins. Anhydrite was also observed in the veins. Crystallization of anhydrite likely occurred later than quartz formation.

The vein mineralogy from Leg $137 / 140$ cores is comparable with secondary mineralogy described in the transition zone and dikes at Hole 504B. Alteration is inferred to have occurred in four general stages with characteristic mineral assemblages: (1) chlorite, actinolite, pyrite, and sphene in veins, and the same minerals plus albite in host rocks; (2) quartz, epidote, and sulfides in veins; (3) anhydrite locally in veins; and (4) zeolites and prehnite in veins and host rocks, and calcite in veins (Alt et al., 1986). This sequence was mainly established on the basis of crosscutting vein relationships, and was related to the movement of the crust away from the spreading axis (Alt et al., 1986, 1989; Dick, Erzinger, Stokking, et al., 1992). Greenschist minerals formed in the rocks during axial hydrothermal alteration at temperatures of $250^{\circ}-380^{\circ} \mathrm{C}$. As the crust moved off-axis, precipitation of anhydrite and, later, of zeolites (at temperatures less than about $150^{\circ} \mathrm{C}$ ) was provided by the penetration of water in a recharge zone.

\footnotetext{
${ }^{1}$ Erzinger, J., Becker, K., Dick, H.J.B., and Stokking, L.B. (Eds.), 1995. Proc, ODP, Sci. Results, 137/140: College Station, TX (Ocean Drilling Program).

${ }^{2}$ Dipartimento di Geologia, Paleontologia e Geofisica, Università di Padova, Via Giotto I, 35137 Padova, Italy.

${ }^{3}$ Department of Earth Sciences, University of Oxford, Parks Road, Oxford OXI 3PR, United Kingdom.

${ }^{4}$ Laboratoire de Pétrologie Magmatique, URA CNRS 1277, Faculté des Sciences et Techniques de Saint-Jérôme. Avenue Escadrille Normandie Niemen, 13397 Marseille Cedex 20, France.
}

Veins are usually interpreted in terms of brittle failure of the rock and subsequently infill by material from circulating supersaturated solutions. Vein microstructures and mineralogy provide information about the mechanism of vein formation and physical conditions at mineral equilibrium. The purpose of this paper is to present a detailed study of the textural features and vein morphology and mineralogy in selected examples from Legs 137/140 cores. Microstructural and chemical data have been used to interpret mechanisms of vein formation. Microstructures were investigated primarily in samples oriented relative to local reference coordinates (i.e., the core barrel frame) to obtain some (albeit limited) structural and tectonic information. Electron microprobe analyses of chlorite + amphibole-bearing veins and amphibole-bearing veins were used to constrain the thermal conditions under which the infilling material crystallized from circulating hydrothermal fluids.

\section{TECTONIC SETTING}

Hole 504B is located about $200 \mathrm{~km}$ south of the Costa Rica Rift. It penetrates $2 \mathrm{~km}$ of a 5.9 -m.y.-old oceanic crust. The half spreading rate of the south flank of the Costa Rica Rift has been estimated at about $3.6 \mathrm{~cm} / \mathrm{yr}$ (Klitgord et al., 1975; Hey et al., 1977; Hobart et al., 1985). To date, Hole 504B represents the most complete reference section through the upper oceanic crust. This section includes, below a 274.5 -m-thick sedimentary cover, $571.5 \mathrm{~m}$ of pillow lavas and flows, underlain by a $209-\mathrm{m}$ transition zone of mixed pillow lavas, thin flows and dikes, and $945.4 \mathrm{~m}$ (at the end of Leg 140) of sheeted dikes and massive units (Fig. 1).

The structural evolution of the crust exposed at Hole 504B is still poorly defined mainly because structural information is not evenly distributed in the overall drilled section. Data collection may not be representative of the entire crustal section, as the recovery percentage is generally low, averaging between $12 \%$ and $20 \%$ (Cann, Langseth, Honnorez, Von Herzen, White, et al., 1983; Anderson, Honnorez, Becker, et al., 1985; Becker, Sakai, et al., 1988). The interpretation of structural data is also limited by the one-dimensional nature of the borehole.

The deformation history of the oceanic rocks so far recovered at Hole 504B is relatively simple and apparently unaffected by slip components that should be active in the nearest (more than $70 \mathrm{~km}$ away) major Ecuador and Panama fracture zones (Agar, 1990). 


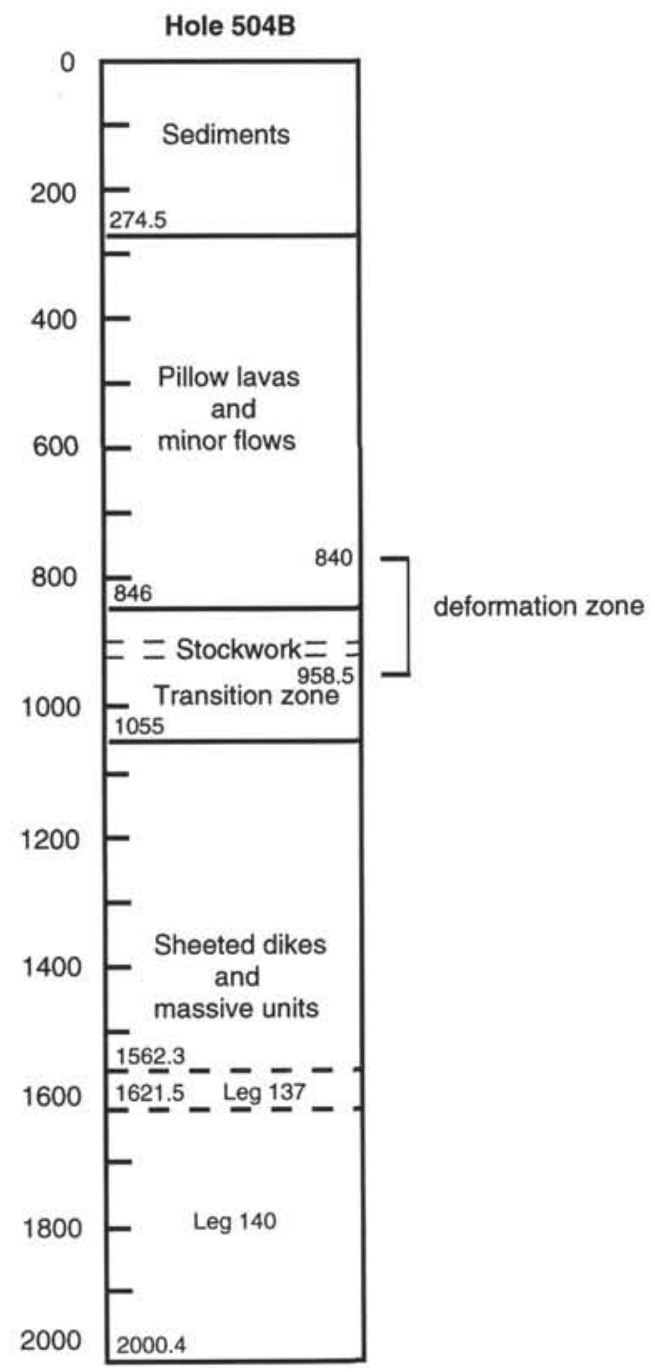

Figure 1. Lithostratigraphy of the crustal section penetrated by Hole 504B with the location of the deformation zone (modified after Agar, 1991). Depth is given in meters below seafloor.

\section{Deformation and Relation to Alteration}

The deformation history from the upper pillow lavas zone to the transition zone has been reconstructed in relation to the hydrothermal alteration at Hole 504B (Alt et al., 1985, 1986; Agar, 1991). The resulting tectonometamorphic evolution starts with early brittle deformation due to thermal contraction associated with cooling of the crust. This event is followed by the first alteration stage, which occurred under greenschist facies conditions (chlorite-actinolite-pyrite-sphene), which affected the matrix of primary breccias. Reactivation of earlier fractures and faults occurred through dominantly dilational structures during the second alteration stage (quartz-epidote-sulfides). Further extensional veining was developed during the last (fourth, according to Alt et al., 1986) lower temperature alteration stage that produced zeolites-prehnite-calcite. Veins of the second and fourth stages of alteration were subsequently reopened in directions suggesting rotation of the local stress field.

The structure of the upper crust exposed at Hole 504B (from 274.5 mbsf to about 846 mbsf, Fig. 1) is characterized by a network of fine-scale fractures, which are attributed to the thermal contraction of the crust as it moved away from the spreading axis (Adamson, 1984, 1985; Agar, 1990). These early thermal cracks may have been reactivated as mode 1 (extensional) fractures probably related to sub- sequent high temperature alteration (Alt et al., 1985). Evidence for mode 2 (shear) failure is scarce. Breccias of various origins have been detected (Agar, 1990).

The crustal zone at the boundary between the lower part of the pillow section and the transition zone (Fig. 1) is considered one of the most deformed intervals in the Hole 504B core (Agar, 1991). This zone extending between $840 \mathrm{mbsf}$ and $958.5 \mathrm{mbsf}$ and corresponding to the so-called "stockwork-like zone" (Adamson, 1985; Anderson, Honnorez, Becker, et al., 1985) is characterized by a change from a fine-scale fracture network in the upper crust downward to a high concentration of fault rocks that are affected by high-temperature $\left(200^{\circ}-350^{\circ} \mathrm{C}\right)$ alteration. Abundant veins, breccias, and (inferred) hydraulic fractures have been observed. Polyphase deformation effects are recognizable on the microscopic scale (Agar, 1991).

The transition zone is mainly characterized by dilational fractures, whereas the effects of non-coaxial deformation are locally revealed by microstructural indicators (Agar, 1990, 1991). In contrast to the upper zone, examples of non-coaxial deformation overprinting dilational cracks have been observed in the transition zone.

The structural evolution of the lower Hole 504B (i.e., the sheeted dike complex) is less known. Published structural data mainly regard crustal fracturing and derive from downhole logging experiments during Leg 83 (Newmark, et al., 1985a, b) and Leg 111 (Morin et al., 1989; Pezard and Anderson, 1989). Structural studies conducted during Leg 140 by core and thin-section observations and by interpretation of FMS images, show that deformation in the lower section of the dike complex is dominated by fracturing on all scales (Dick, Erzinger, Stokking, et al., 1992). Nevertheless, no important zones of intense deformation were recognized. Evidence of faulting is rare and recognizable only at the microscope scale (Dick, Erzinger, Stokking, et al., 1992).

\section{DESCRIPTION OF VEINS}

\section{Vein Geometry and Orientation}

At least seven macroscopic vein types may be recognized in the diabase samples from Legs 137/140, according to their color in hand specimens (Dick, Erzinger, Stokking, et al., 1992). On the basis of vein-filling minerals, these categories may be reduced to the following five: chlorite-bearing, chlorite and amphibole-bearing, amphibole-bearing, chlorite and pyrite-bearing, epidote and quartz-bearing veins. These veins range from $<0.5 \mathrm{~mm}$ to about $2 \mathrm{~mm}$ in width. Mostly amphibole-, amphibole + chlorite-, and chlorite-bearing veins are surrounded by millimetric halos, in which alteration is usually more extensive $(40 \%-90 \%)$ than in the adjacent rock. Halos around veins may exhibit a zonation in the extent of alteration that is reflected by different color in hand specimens. Namely, inner dark zones correspond to higher alteration percentage, whereas outer lighter zones correspond to lower alteration percentage (Pl. 1, Fig. 1).

Veins in Leg 137/140 cores are evenly distributed with depth and a significant reduction in vein abundance is recognizable below 1850 mbsf. An average of 15 veins $/ \mathrm{m}$ of recovered core has been recorded (Dick, Erzinger, Stokking, et al., 1992). Structural data collected from the cores indicate the morphological characters of veins and their space orientation (Dick, Erzinger, Stokking, et al., 1992). In hand specimens veins appear morphologically uniform, being planar $(77 \%)$ or curvilinear to sinuous. Only a few veins have been observed with anastomosing or branching shapes. In one case, composite veins have been observed that likely developed from a typical overlapping crack system (Pollard and Aydin, 1988) and then propagated through the rock as a single vein (Pl. 1., Fig. 1). True dip data suggest that veins are mostly shallowly dipping with only smaller peaks of steeply dipping orientation for the chlorite- and amphibole + chlorite-bearing veins. Paleomagnetic corrections applied to a small part of the overall detected veins suggest a random distribution of dip directions with a dominantly shallow orientation (Dick, Erzinger, Stokking, et al., 1992, fig. 78). These data have been interpreted as the result of super- 
position of two vein sets, one of which is shallowly dipping and the other is random. The shallowly dipping trend may indicate the presence of a compressive regime. The random fabric may be related to local stress conditions dominated by high fluid pressure and/or contractional cooling, rather than by a regional tectonic regime.

\section{Microscopic Observations}

Selected examples of veins from the diabase cores have been observed in thin section to study their morphology, the arrangement of the vein-filling minerals, and any possible indicators of deformation.

Almost all the veins exhibit planar to curvilinear shapes, which may locally branch or anastomose. Several examples of veins branching into two thinner veins leaving an isolated lense-shaped portion of diabase rock in between were observed in Samples 140-504B-186R1, 53-57 cm (Piece 10); 140-504B-186R-1, 71-76 cm (Piece 13A); 140-504B-198R-1, 21-25 cm (Piece 6); 140-504B-200R-1, 105-107 $\mathrm{cm}$ (Piece 15). These veins probably originated as overlapping cracks that coalesced during their propagation (Dick, Erzinger, Stokking, et al., 1992). Similar vein sets were recognized in hand specimens (Sample 140-504B-190R-1, 75-79 cm, Piece 17 (Pl. 1, Fig. 1). A stepped vein was observed in Sample 140-504B-213R-1, 3-6 cm, Piece 2 (Pl. 1, Fig. 2). This vein is about $400 \mu \mathrm{m}$ wide and filled with fine-grained clinopyroxene, minor amphibole, and magnetite. The vein-filling minerals are not deformed. The vein was reopened by the intrusion of a second vein (magmatic dikelet?), 300-500 $\mu \mathrm{m}$ wide and formed by albite, actinolite, and magnetite. The stepped vein may arise from the filling of a fracture with a tilted path (mixed mode $1+2$; Pollard and Aydin, 1988),

Almost all the veins, especially amphibole- and chlorite + amphibole-bearing veins, are characterized by irregular walls. This morphology is inherited by the shape of the igneous minerals that are replaced in the wallrock. In fact, in many veins amphibole fibers grow epitaxially on clinopyroxene crystals of the wallrock, exhibiting the same cleavage orientation (Pl. 1, Fig. 3). This suggests that syntaxial overgrowth of mineral phases in crack walls occurred during the earliest stages of fracturing and fluid circulation (Durney and Ramsay, 1973; Ramsay, 1980; Cox and Etheridge, 1983). The orientation of amphibole in these veins is variable along the vein, being mainly controlled by the crystallographic orientation of clinopyroxene in the vein edges (see below).

The distribution of the vein-filling minerals along the vein reflects the igneous minerals in the wallrock: in amphibole- and in chlorite + amphibole-bearing veins, chlorite occurs in the vein when the wall is plagioclase, and actinolite when the wall is clinopyroxene. However, monomineralic veins may also develop when more than one mineral species occurs in the vein walls.

\section{Vein Fill Textures}

The arrangement of the vein-filling minerals may be of different types:

1. Stretched amphibole crystals (= "stretched fibers"; Durney and Ramsay, 1973; Ramsay and Huber, 1983) linking the walls of monomineralic veins or rimming the edges of multiply opened veins (Sample 140-504B-197R-1, 99-101 cm, Piece 22; Pl. 1, Fig. 4). In this latter sample, the long axes of the amphibole crystals are orthogonal to the vein walls but stretched fibers inclined at lower angle to the vein wall were also observed (see also Agar and Marton, this volume). In the studied veins, the orientation of the fibers is strongly controlled by the crystallographic orientation of the clinopyroxene crystals replaced in the wallrock (syntaxial overgrowth). In multiply opened veins, the stretched fibers formed by syntaxial overgrowth on clinopyroxene during the earliest stages of vein opening and they were subsequently broken during later reopening stages (PI. 1, Fig. 4). In some examples, the continuous crystallographic orientation of the stretched amphibole crystals is overprinted by kinking or bending (Plate 2, Fig. 1).

2. Random orientation of crystals, especially of amphibole (Samples 140-504B-186R-1, 57-60 cm, Piece 10; 140-504B-186R-1, 81$84 \mathrm{~cm}$, Piece 13B; 140-504B-189R-1, 105-106 cm, Piece 21B; Pl. 2 , Fig. 1). The orientation of amphibole crystals is variable along the vein, but the shape orientation of crystals is at a high angle to the vein walls. Bent amphibole crystals are very frequent, especially in the middle of veins (Pl. 2, Fig. 1; see also Pl. 1, Fig. 3).

3. Zoning patterns are shown by a few veins: Samples 140-504B186R-1, 21-23 cm, Piece 5 (Pl. 1, Fig. 3); 140-504B-197R-1, 99-101 cm, Piece 22 (Pl. 1, Fig. 4); 140-504B-198R-1, 70-71 cm, Piece 18. In Sample 140-504B-186R-1, 21-23 cm (Piece 5), the zoning pattern of a $300-\mu \mathrm{m}$-wide monomineralic vein is characterized by outer amphibole fibers that are syntaxially overgrown on clinopyroxene of the wallrock. In the middle of the vein, amphibole crystals are deformed by bending but are randomly oriented. In Sample 140-504B-197R-1, 99-101 cm (Piece 22), amphibole crystals are oriented perpendicular to the vein walls in the outer zones and parallel to the vein in the inner zone where they are associated with opaque seams (PI. 1, Fig. 4). Zoning patterns in the vein-filling process suggests that several distinct opening stages may have taken place during vein evolution.

4. Another pattern is represented by epidote + quartz vein in Sample 140-504B-192R-1, 13-15 cm (Piece 4). Epidote forms acicular elongated crystals gathered into radial aggregates and occupying about one-half of the vein width (Dick, Erzinger, Stokking, et al., 1992). The arrangement of epidote in radiating prisms oriented subperpendicular to the growth surface suggests crystallization in an open cavity (Durney and Ramsay, 1973).

\section{Vein Deformation}

Most of the veins studied seem to have grown under stress conditions dominated by extensional regime in the brittle domain. In thin section, veins appear locally deformed, and deformation does not extend to the surrounding portion of the rock.

The following examples were selected for describing deformed textures in veins:

1. Bent amphibole crystals in Samples 140-504B-186R-1, 21-23 $\mathrm{cm}$ (Piece 5); 140-504B-189R-1, 105-106 cm (Piece 21B; Pl. 1, Fig. 3 , and Pl. 2, Fig. 1, respectively), which locally appear to be broken (PI. 2, Fig. 1). Deformed crystals exhibit wavy extinctions. The shape orientation of the crystals is usually random inside the same vein.

2. En-echelon cracks and tension gashes by simple shear inside amphibole crystals-filling veins (e.g., Samples 140-504B-186R-1, 53-57 cm, Piece 10; 140-504B-186R-1, 57-60 cm, Piece 10; Fig. 2). Tension gashes are filled with zeolites (see below). The orientation (paleomagnetically corrected) of the amphibole + chlorite veins in these two samples is $42 \% 1.9$ (dip angle/dip direction) and $29^{\circ} / 315.9$, respectively (Dick, Erzinger, Stokking, et al., 1992). The geometry of tension gashes relative to the vein and core orientation (Fig. 2) suggests a sense of shear consistent with reverse faulting. Small "pullapart" type openings are produced by shear in a vein cutting a centimeter-sized clinopyroxene phenocryst (Sample 140-504B186R-1, 17-26 cm, Piece 5; Fig. 3). In the voids of the pull-aparts, clasts of the host clinopyroxene, subsequently altered into amphibole, are supported by a chlorite + actinolite matrix. The orientation of vein is $27 \% 190$ (true orientation calculated from apparent measurements). From the geometry of these pull-aparts and the orientation of the core, a sense of shear consistent with reverse faulting may be argued (Fig. 3). Offsets (simple shear?) along crosscutting vein sets were observed in Samples 140-504B-186R-1, 53-57 cm (Piece 10); 140-504B198R-1, 70-71 cm (Piece 18), and 140-504B-203R-1, 33-36 cm (Piece 10; Fig. 4). Offsets never exceed $10 \mathrm{~mm}$. In Sample 140-504B203R-1, 33-36 cm (Piece 10), shear zones are concentrated along the contact between a chilled rock portion and the host diabase (PI. 2, Fig. 

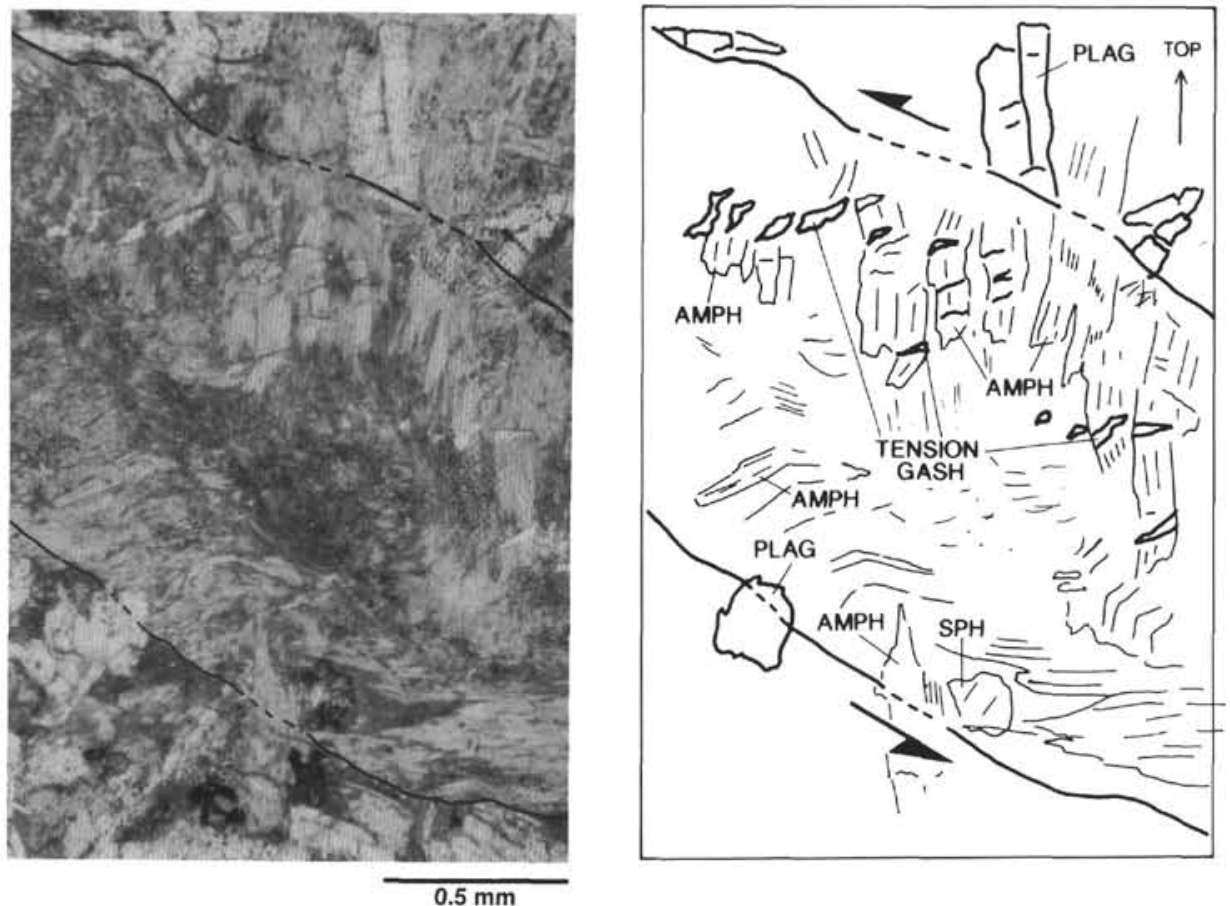

Figure 2. Tension gashes (zeolites-filled) inside an amphibole vein (Sample 140-504B-186R-1,53-57 cm, Piece 10). Arrows show the sense of shear as inferred from the tension gashes' geometry. The top of the thin section is indicated according to the core orientation. $A M P H=$ amphibole; $P L A G=$ plagioclase; $S P H=$ sphene .

2). Shearing is associated with brecciation; evidence of this comes from the offset of thin veins that crosscut the chilled margin (Pl. 2, Fig. 2). Veins are filled by bent amphibole fibers. In the dike chilled zone, crosscutting relations between veins show a sense of offset, which is consistent with the sense of displacement as inferred in the shear zone (sample is not oriented).

3. Veins from the recovered samples frequently show evidence of brecciation. Small portions of the phenocrysts, or of the groundmass that are intersected by veins, are observed inside the veins. Clasts usually have a rounded shape and are enclosed in a fine-grained matrix consisting of chlorite and amphibole. Clinopyroxene clasts are replaced by amphibole and are most abundant where veins cut clinopyroxene phenocrysts, whereas plagioclase clasts are most abundant where vein intersects plagioclase phenocrysts in the groundmass (Sample 140-504B-186R-1, 13-14 cm, Piece 4; Dick, Erzinger, Stokking, et al., 1992). Other examples of brecciation are found in Samples 140-504B-186R-1, 17-26 cm (Piece 5); 140-504B-189R-1, 105-106 cm, (Piece 21B); 140-504B-221R-1, 11-15 cm (Piece 4; Pl. 2, Fig. 3). In this latter sample, millimetric zones of cataclasis are characterized by strong reduction of grain size (from about $1 \mathrm{~mm}$ to $0.05 \mathrm{~mm}$ of length of plagioclase laths). Clasts have usually irregular shapes and are supported by amphibole matrix (Pl. 2, Fig. 3). Brecciation could be related to either hydrofracturing or microfaulting or to both. The shapes of clasts are usually rounded off and do not fit together suggesting that breccias zone were partly affected by microfaulting.

\section{Crosscutting Relations}

Microscopic observations of crosscutting relations between vein sets do not lead to a definitive and consistent sequence of events, as already seen by macroscopic observations. Crosscutting geometries are basically of three types:

1. Offset of older veins by younger veins as in Samples 140504B-186R-1, 53-57 cm (Piece 10; Fig. 4); 140-504B-198R-1, 70$71 \mathrm{~cm}$ (Piece 18).
2. No apparent offset,

3. One vein emerges from another vein (T-intersections; Pollard and Aydin, 1988) as in Samples 140-504B-197R-1,99-101 cm (Piece 22; Pl. 2, Fig. 4), and 140-504B-197R-2, $9 \mathrm{~cm}$ (Piece 2).

\section{MINERAL CHEMISTRY}

\section{Analytical Techniques}

The composition of some vein-filling minerals was analyzed by a computer-controlled electron-probe microanalyzer (EMPA) at the Petrology Department of the University of Padova (Italy), at the IFREMER Institut of Brest (France), and at the Laboratoire de Petrologie of the UPMC of Paris (France). Cameca "CAMEBAX" and CAMECA MBX EMPA systems were used. Analytical conditions were at $15 \mathrm{kV}$ of accelerating voltage and $15 \mathrm{nA}$ of current intensity. Natural and synthetic phases were used as standards.

Calculation of the structural formula of amphibole has been conducted on the basis of 23 oxygens by utilizing the "AMPHIBOL.EXE" program performed at the Laboratoire de Petrologie Magmatique of the Marseille University. Iron repartition has been obtained by this program on the basis of five different normalization methods: $\mathrm{Si}=8$ (no tetrahedral $\mathrm{Al}$ ); $\mathrm{SUMMG}=13$ (normalization to 13 of the sum $\mathrm{Si}+\mathrm{Al}+\mathrm{Ti}+\mathrm{Fe}^{2+}+\mathrm{Mn}$ ); $\mathrm{SUMCA}=15$ (normalization to 15 of the sum: $\mathrm{Si}+\mathrm{Al}+\mathrm{Ti}+\mathrm{Fe}^{3+}+\mathrm{Mg}+\mathrm{Fe}^{2+}+\mathrm{Mn}+\mathrm{Ca}+\mathrm{Na}$ ); SUMNA $=15$ (normalization to 15 of the sum $\mathrm{Si}+\mathrm{Al}+\mathrm{Ti}+\mathrm{Fe}^{3+}+$ $\left.\mathrm{Mg}+\mathrm{Fe}^{2+}+\mathrm{Mn}+\mathrm{Ca}+\mathrm{Na}\right)$. One method was selected when the conditions suggested by Papike et al. (1974) were satisfied.

The structural formula of clinopyroxene was calculated on the basis of six oxygens, using the MINTAB program for the Apple Macintosh computer (Rock and Carroll, 1990) based on the procedure proposed by Droop (1987).

Structural formulae of laumontite and heulandite were obtained on the basis of 12 and 18 oxygens, respectively, and assuming all the iron to be ferrous. 

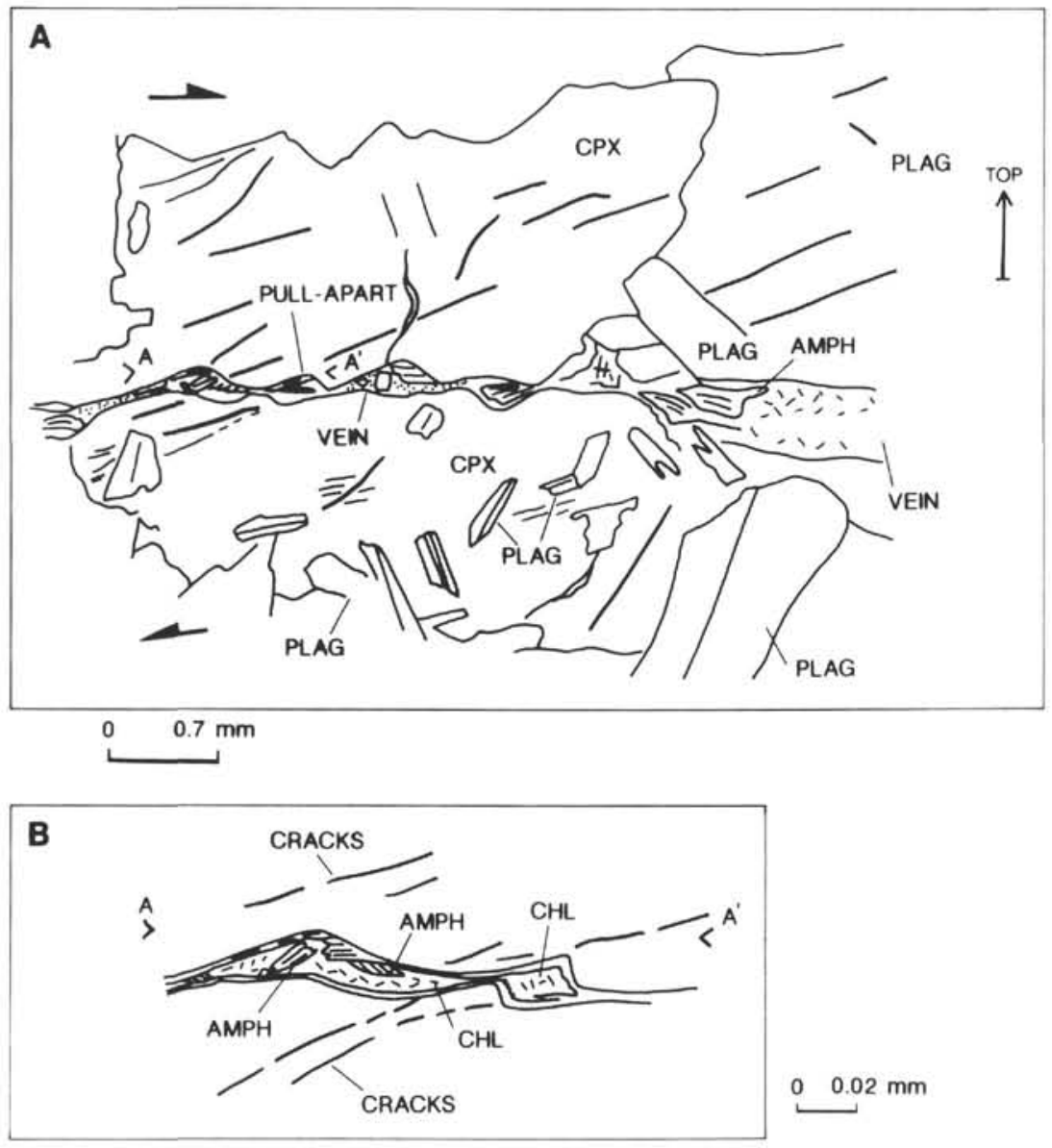

$0 \quad 0.02 \mathrm{~mm}$

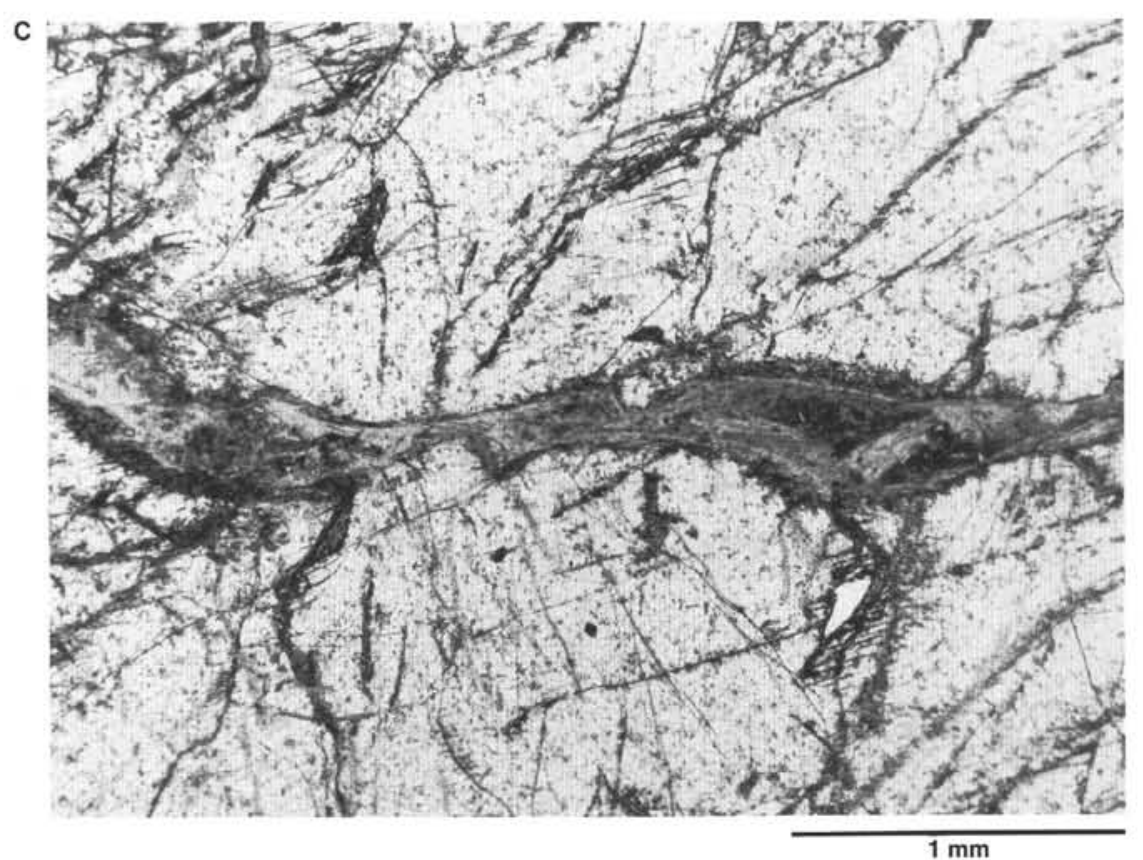

Figure 3. Pull-apart structures in a vein cutting a centimeter-sized clinopyroxene phenocryst (Sample 140-504B-186R-1, 17-26 cm, Piece 5). A. Clinopyroxene phenocryst cut by a vein with pull-aparts. $\mathrm{CPX}=$ clinopyroxene phenocryst; $\mathrm{PLAG}=$ plagioclase phenocrysts and laths; $\mathrm{AMPH}=$ amphibole inside the vein; $\mathrm{AA}{ }^{\prime}$ $=$ part of the vein illustrated by the photomicrograph and by sketch B. The top of thin section is indicated according to the core orientation. B. Detailed sketch of the vein with pull-aparts structures as shown in the photomicrograph. $\mathrm{AMPH}=$ amphibole $\mathrm{CHL}=$ chlorite; $\mathrm{CRACKS}=$ microfractures in the host clinopyroxene. C. Photomicrograph of the pull-aparts structures in the vein (dark gray) cutting clinopyroxene (light gray). Plane light. 


\section{Amphibole}

Amphibole is one of the most common vein-filling minerals in the Hole 504B Legs $137 / 140$ cores. It also occurs in the alteration halos around veins and in the groundmass outside the halos where it is present as interstitial mineral or as replacement of igneous clinopyroxene. Interstitial amphibole is of uncertain origin and a clear connection with primary clinopyroxene cannot be identified. Amphibole has been analyzed in the following textural sites: (1) inside veins, (2) along the vein walls, replacing igneous clinopyroxene of the wallrock, (3) in alteration halo around veins, and (4) in the groundmass, away from the halo, either as interstitial mineral or replacing clinopyroxene.

No important chemical difference was detected between undeformed and deformed amphiboles and no zonation was observed inside single crystals. This could be interpreted as a bias due to the extremely reduced grain size of the fibers that makes it difficult to analyze transect across the fibers.

Most of the vein-filling amphiboles are actinolite (Leake, 1978; Table 1). Actinolite is very common, representing about $55 \%$ of the analyzed amphibole in veins, about $54 \%$ in vein walls, $19 \%$ in halos and $36 \%$ in the groundmass (Laverne et al., this volume). In veins, actinolitic hornblende is also abundant (Table 1, analysis V5169), and it is usually characterized in thin section by a bluish-dark green color. Cummingtonite and edenite were found in minor amount inside the veins (Table 1, analyses V3064 and B2186). In some veins, Mg-hornblende occurs in aggregates of needle-shaped fibers that are mostly associated with zeolite in apparent equilibrium (Table 1, analysis V4112).

Amphibole that crystallized along the vein walls (syntaxial on clinopyroxene) is mainly composed of actinolite and actinolitic hornblende (Table 1, analyses V4080 and V1016). In multiply opened veins, hornblende (s.l.) crystallized along the vein walls (not represented in Table 1), while the vein center is filled with actinolite.

In the alteration halo around veins, amphibole is mostly actinolitic hornblende and $\mathrm{Fe}$-actinolite, but actinolite, $\mathrm{Mg}$-hornblende, and cummingtonite were also found (Table 1).

Amphibole occurring in the groundmass either as an interstitial crystal or after igneous clinopyroxene mostly exhibits actinolitic composition (Table 1) and, more rarely, actinolitic hornblende, $\mathrm{Mg}$ hornblende, and edenite.

The occurrence of widespread actinolite inside the veins and in the host rock suggests temperatures during fluid circulation around $300^{\circ} \mathrm{C}$; however, actinolitic hornblende and $\mathrm{Mg}$-hornblende that are more frequent in the halos and in the vein walls would be consistent with even higher temperatures. On the other hand, it must be taken into account that, in the rocks studied here, amphibole composition appears strongly dependent on microstructural site, (i.e., vein or wallrock, vein wall, and halo), and it could be ascribed to the textural context more than to a temperature. In the wallrock, for example, minerals of the igneous paragenesis could have been involved during the reaction producing amphibole. This could explain the variation in the $\mathrm{Mg}$ number, especially in amphibole from the alteration halo (Fig. 5). The Mg number shows the lowest value in Fe-actinolite occurring in halo (analysis V5144 in Table 1). The iron enrichment in this amphibole may be explained by involving Fe-oxide, that is present in the wallrock, during the metamorphic reaction producing amphibole. Iron-rich amphibole has never been analyzed inside veins. Amphibole along the vein walls (syntaxial overgrowth on clinopyroxene) is usually characterized by a higher percentage of $\mathrm{Cr}_{2} \mathrm{O}_{3}$ with respect to amphibole that grows in the middle of veins. Similarly, amphibole that replaces clinopyroxene in the alteration halo or in the groundmass (away from the halo) exhibits relatively higher $\mathrm{Cr}$ content, suggesting that $\mathrm{Cr}$ is not mobilized during the clinopyroxene alteration. Primary clinopyroxenes in basalts from Hole 504B were analyzed in upper crustal sections and show $\mathrm{Cr}$ content as high as 1.21 $\mathrm{Cr}_{2} \mathrm{O}_{3} \%$ (Kempton et al., 1985).

Other chemical variations were observed among the analyzed amphiboles, which are not apparently related to microstructural site.
For instance, Ti content shows strong variation, and the highest values were obtained in edenite, $\mathrm{Mg}$-hornblende, and act-hornblende from both veins and wallrock. $\mathrm{Cl}$ content is also extremely variable, but a clear correlation of $\mathrm{Cl}$ with tetrahedral $\mathrm{Al}$ was observed (analyses B2187, B2186, B3037 in Table 1). Moreover, relatively higher Al IV values are accompanied by relatively higher Ti content (same analyses in Table 1) or FeO content (analysis V5144 in Table 1). Correlation of $\mathrm{Cl}$ with $\mathrm{Al}$ IV has already been noted by Mével (1984), Vanko (1986), Suwa et al. (1987), Castelli (1988), Morrison (1991), and Enami et al. (1992), whereas Gulyaeva et al. (1986) and Suwa et al. (1987) showed high $\mathrm{Cl}$ values only in Fe-rich amphiboles. Such correlations among $\mathrm{Cl}, \mathrm{Al} \mathrm{IV}$, and $\mathrm{Fe}^{2+}$ have been explained recently in terms of crystal structure of calcic amphiboles (Oberti et al., 1993).

\section{Clinopyroxene}

Fine-grained secondary clinopyroxene fills a $0.4-\mathrm{mm}$-wide vein in Sample 140-504B-213R-1, 3-6 cm (Piece 2; Pl. 1, Fig. 2). Representative analyses of clinopyroxene are reported in Table 2 . It is composed of diopside with variable $\mathrm{Fe}$ and $\mathrm{Ca}$ contents; namely clinopyroxenes with lower $\mathrm{Fe}$ contents are enriched in $\mathrm{Ca}$ (analyses $\mathrm{Cl}$ and C9 in Table 2) and vice versa (analyses C2 and C8). Unlike magmatic augite (Laverne et al., this volume), diopside does not contain detectable $\mathrm{Cr}_{2} \mathrm{O}_{3} \%$, and differs from other secondary clinopyroxene, detected in samples between 1595 and 1619 mbsf, in that it does not show anomalous $\mathrm{Ti}$ and $\mathrm{Na}$ contents (Laverne et al., this volume). In association with clinopyroxene of Sample 140-504B-213R-1, 3-6 cm, scarce amphibole (Mg-hornblende) occurs as probable older relict mineral inside the vein.

Secondary clinopyroxene has been found in gabbros from the Southwest Indian Ridge at Site 735B (Stakes et al., 1991) and from the Mid-Atlantic Ridge, in the vicinity of the Kane Fracture Zone (Gillis et al., 1993). Clinopyroxene fills veins and shows composition similar to that of Sample 140-504B-213R-1,3-6 cm, although richer in $\mathrm{Ca}$ and poorer in $\mathrm{Fe}$. Secondary diopside has also been described in gabbroic dikelets crosscutting peridotites from the Atlantic MARK area (Tartarotti et al., unpubl. data) and shows higher $\mathrm{Mn}$ and $\mathrm{Ca}$ in respect to diopside in Sample 140-504B-213R-1, 3-6 cm. Clinopyroxene from the Southwest Indian Ridge and from the Atlantic has been interpreted of hydrothermal origin.

\section{Zeolites}

Zeolites fill tension gashes opened within actinolite crystals filling the veins in Samples 140-504B-186R-1, 53-57 cm (Piece 10); 140504B-186R-1, 57-60 cm (Piece 10), and 140-504B-189R-1, 106-110 $\mathrm{cm}$ (see Fig. 2). Representative analyses of the zeolites filling tension gashes are reported in Table 3 . These zeolites are composed of laumontite in Sample 140-504B-186R-1, 57-60 cm, and of heulandite (or stilbite?) in Sample 140-504B-189R-1, 106-110 cm (Table 3). In Sample 140-504B-186R-1, 57-60 cm, zeolite also fills interstitial spaces, with hornblende needles occurring in the central part of the actinolitic veins. This zeolite shows composition of laumontite (analyses V4108, V4111 in Table 3).

The occurrence of laumontite filling interstitial pore space in veins is indicative of circulation of late-stage, relatively low-temperature fluids. The upper thermal stability of laumontite is about $230^{\circ} \mathrm{C}$ (Liou, 1971), which is a lower temperature than that inferred for the stability of actinolite, which forms the main infill of the veins.

\section{DISCUSSION}

\section{Structural Interpretation}

The morphology of veins as observed in hand specimen and in thin section, and the arrangement of the vein-filling minerals, suggest that the veins studied here formed under an extensional regime in a brittle domain (Ramsay and Huber, 1983; "extensional fissures"). Veins 
Table 1. Representative analyses of amphibole from Hole 504B, Leg 140.

\begin{tabular}{|c|c|c|c|c|c|c|c|c|c|c|c|c|c|c|}
\hline $\begin{array}{l}\text { Sample: } \\
\text { Analysis: } \\
\text { Occurrence: }\end{array}$ & $\begin{array}{c}\text { I86R-1, } \\
21-23 \\
\text { V4083 } \\
\text { ACT } \\
\text { vein }\end{array}$ & $\begin{array}{c}186 R-1, \\
57-60 \\
\text { V4103 } \\
\text { ACT } \\
\text { vein }\end{array}$ & $\begin{array}{c}186 \mathrm{R}-1, \\
140-143 \\
\text { B3107 } \\
\text { ACT } \\
\text { vein }\end{array}$ & $\begin{array}{c}204 \mathrm{R}-1, \\
11-14 \\
\text { V5169 } \\
\text { Act-HBL } \\
\text { vein }\end{array}$ & $\begin{array}{c}214 \mathrm{R}-1 \text {, } \\
67-70 \\
\mathrm{~B} 2187 \\
\mathrm{Mg}-\mathrm{HBL} \\
\text { vein }\end{array}$ & $\begin{array}{c}200 R-2, \\
18-24 \\
\text { V3064 } \\
\text { CUMM } \\
\text { vein }\end{array}$ & $\begin{array}{c}214 \mathrm{R}-1 \\
67-70 \\
\text { B2186 } \\
\text { EDEN } \\
\text { vein }\end{array}$ & $\begin{array}{c}186 R-1, \\
57-60 \\
\text { V4112 } \\
\text { Mg-HBL } \\
\text { vein }\end{array}$ & $\begin{array}{c}\text { 186R-1. } \\
21-23 \\
\text { V } 4080 \\
\text { ACT } \\
\text { vein wall }\end{array}$ & $\begin{array}{c}236 \mathrm{R}-\mathrm{I} \text {, } \\
67-68 \\
\mathrm{~V} 1016 \\
\text { Act-HBL } \\
\text { vein wall }\end{array}$ & $\begin{array}{c}189 \mathrm{R}-1, \\
106-110 \\
\text { V5144 } \\
\text { Fe-ACT } \\
\text { halo }\end{array}$ & $\begin{array}{c}\text { 223R-1, } \\
9-11 \\
\text { B3025 } \\
\text { Act-HBL } \\
\text { halo }\end{array}$ & $\begin{array}{c}230 \mathrm{R}-1 \\
14-17 \\
\mathrm{~B} 3037 \\
\mathrm{Mg}-\mathrm{HBL} \\
\text { halo }\end{array}$ & $\begin{array}{c}\text { 197R-1, } \\
44-46 \\
\text { B3069 } \\
\mathrm{ACT} \\
\text { groundmass }\end{array}$ \\
\hline $\begin{array}{l}\mathrm{SiO}_{2} \\
\mathrm{Al}_{2} \mathrm{O}_{3} \\
\mathrm{FeO}_{1} \\
\mathrm{MnO} \\
\mathrm{MgO} \\
\mathrm{CaO} \\
\mathrm{Na}_{2} \mathrm{O} \\
\mathrm{K}_{2} \mathrm{O} \\
\mathrm{TiO}_{2} \\
\mathrm{Cr}_{2} \mathrm{O}_{3} \\
\mathrm{ZnO} \\
\mathrm{Cl}\end{array}$ & $\begin{array}{r}52.87 \\
2.27 \\
19.91 \\
0.26 \\
11.94 \\
10.22 \\
0.25 \\
0.00 \\
0.04 \\
0.02 \\
0.05 \\
0.06\end{array}$ & $\begin{array}{r}52.41 \\
2.83 \\
17.07 \\
0.19 \\
13.90 \\
10.98 \\
0.40 \\
0.02 \\
0.14 \\
0.00 \\
0.00 \\
0.09\end{array}$ & $\begin{array}{r}52.74 \\
3.44 \\
13.14 \\
0.18 \\
16.11 \\
10.61 \\
0.50 \\
0.00 \\
0.54 \\
0.08 \\
0.00 \\
0.13\end{array}$ & $\begin{array}{r}50.49 \\
3.35 \\
14.55 \\
0.22 \\
14.05 \\
12.22 \\
0.40 \\
0.00 \\
0.52 \\
0.21 \\
0.15 \\
0.02\end{array}$ & $\begin{array}{r}48.02 \\
6.91 \\
13.87 \\
0.27 \\
14.70 \\
11.05 \\
1.23 \\
0.06 \\
1.02 \\
0.00 \\
0.00 \\
0.23\end{array}$ & $\begin{array}{r}53.30 \\
1.97 \\
19.02 \\
0.75 \\
17.12 \\
4.16 \\
0.46 \\
0.02 \\
0.20 \\
0.14 \\
0.00 \\
0.05\end{array}$ & $\begin{array}{r}47.27 \\
7.39 \\
13.49 \\
0.23 \\
14.76 \\
10.80 \\
1.78 \\
0.24 \\
1.09 \\
0.00 \\
0.00 \\
0.30\end{array}$ & $\begin{array}{r}48.82 \\
8.03 \\
12.65 \\
0.25 \\
14.59 \\
11.96 \\
1.19 \\
0.05 \\
0.50 \\
0.01 \\
0.00 \\
0.10\end{array}$ & $\begin{array}{r}52.58 \\
2.58 \\
17.63 \\
0.27 \\
13.60 \\
10.80 \\
0.26 \\
0.01 \\
0.20 \\
0.19 \\
0.00 \\
0.03\end{array}$ & $\begin{array}{r}51.64 \\
4.23 \\
15.80 \\
0.28 \\
13.55 \\
11.41 \\
0.67 \\
0.03 \\
0.28 \\
0.01 \\
0.02 \\
0.05\end{array}$ & $\begin{array}{r}51.59 \\
1.28 \\
26.81 \\
0.61 \\
7.89 \\
10.12 \\
0.21 \\
0.03 \\
0.12 \\
0.02 \\
0.09 \\
0.11\end{array}$ & $\begin{array}{r}50.12 \\
4.55 \\
15.69 \\
0.25 \\
13.31 \\
11.45 \\
0.88 \\
0.01 \\
0.68 \\
0.10 \\
0.00 \\
0.06\end{array}$ & $\begin{array}{r}50.10 \\
5.18 \\
15.81 \\
0.16 \\
13.69 \\
10.96 \\
0.93 \\
0.08 \\
1.01 \\
0.21 \\
0.00 \\
0.34\end{array}$ & $\begin{array}{r}53.13 \\
2.25 \\
15.97 \\
0.16 \\
13.96 \\
11.91 \\
0.25 \\
0.01 \\
0.05 \\
0.00 \\
0.00 \\
0.00\end{array}$ \\
\hline Total & 97.89 & 98.03 & 97.47 & 96.18 & 97.36 & 97.19 & 97.35 & 98.15 & 98.15 & 97.97 & 98.88 & 97.10 & 98.47 & 97.69 \\
\hline $\begin{array}{l}\text { Si } \\
\mathrm{Al} \text { IV } \\
\mathrm{Al} \text { VI } \\
\mathrm{Ti} \\
\mathrm{Cr} \\
\mathrm{Fe}^{2+} \\
\mathrm{Fe}^{3+} \\
\mathrm{Mn} \\
\mathrm{Mg} \\
\mathrm{Mg}_{\mathrm{M} 4} \\
\mathrm{Ca} \\
\mathrm{Na}_{\mathrm{M} 4} \\
\mathrm{Na}_{\mathrm{A}} \\
\mathrm{K}\end{array}$ & $\begin{array}{l}7.798 \\
0.202 \\
0.193 \\
0.004 \\
0.002 \\
2.387 \\
0.069 \\
0.032 \\
2.312 \\
0.313 \\
1.615 \\
0.071 \\
0.000 \\
0.000\end{array}$ & $\begin{array}{l}7.650 \\
0.350 \\
0.136 \\
0.015 \\
0.000 \\
2.017 \\
0.066 \\
0.023 \\
2.741 \\
0.283 \\
1.717 \\
0.000 \\
0.113 \\
0.004\end{array}$ & $\begin{array}{l}7.552 \\
0.448 \\
0.132 \\
0.058 \\
0.009 \\
1.245 \\
0.329 \\
0.022 \\
3.205 \\
0.233 \\
1.628 \\
0.139 \\
0.000 \\
0.000\end{array}$ & $\begin{array}{l}7.470 \\
0.530 \\
0.054 \\
0.058 \\
0.025 \\
1.580 \\
0.221 \\
0.028 \\
3.035 \\
0.063 \\
1.937 \\
0.000 \\
0.115 \\
0.000\end{array}$ & $\begin{array}{l}7.027 \\
0.973 \\
0.218 \\
0.112 \\
0.000 \\
1.527 \\
0.170 \\
0.033 \\
2.939 \\
0.268 \\
1.732 \\
0.000 \\
0.349 \\
0.011\end{array}$ & $\begin{array}{l}7.740 \\
0.260 \\
0.077 \\
0.022 \\
0.016 \\
2.062 \\
0.248 \\
0.092 \\
2.482 \\
1.223 \\
0.647 \\
0.130 \\
0.000 \\
0.004\end{array}$ & $\begin{array}{l}6.962 \\
1.038 \\
0.245 \\
0.121 \\
0.000 \\
1.662 \\
0.000 \\
0.029 \\
2.944 \\
0.296 \\
1.704 \\
0.000 \\
0.508 \\
0.045\end{array}$ & $\begin{array}{l}7.040 \\
0.960 \\
0.405 \\
0.054 \\
0.001 \\
1.422 \\
0.104 \\
0.031 \\
2.984 \\
0.152 \\
1.848 \\
0.000 \\
0.333 \\
0.009\end{array}$ & $\begin{array}{l}7.677 \\
0.323 \\
0.121 \\
0.022 \\
0.022 \\
2.092 \\
0.061 \\
0.033 \\
2.649 \\
0.311 \\
1.689 \\
0.000 \\
0.074 \\
0.002\end{array}$ & $\begin{array}{l}7.447 \\
0.553 \\
0.166 \\
0.030 \\
0.001 \\
1.399 \\
0.507 \\
0.034 \\
2.863 \\
0.050 \\
1.763 \\
0.187 \\
0.000 \\
0.006\end{array}$ & $\begin{array}{l}7.837 \\
0.163 \\
0.066 \\
0.014 \\
0.002 \\
3.406 \\
0.000 \\
0.078 \\
1.434 \\
0.353 \\
1.647 \\
0.000 \\
0.062 \\
0.006\end{array}$ & $\begin{array}{l}7.403 \\
0.597 \\
0.195 \\
0.076 \\
0.012 \\
1.938 \\
0.000 \\
0.031 \\
2.749 \\
0.181 \\
1.812 \\
0.000 \\
0.252 \\
0.002\end{array}$ & $\begin{array}{l}7.196 \\
0.804 \\
0.072 \\
0.109 \\
0.024 \\
1.165 \\
0.734 \\
0.019 \\
2.876 \\
0.054 \\
1.687 \\
0.259 \\
0.000 \\
0.015\end{array}$ & $\begin{array}{l}7.747 \\
0.253 \\
0.133 \\
0.005 \\
0.000 \\
1.910 \\
0.037 \\
0.020 \\
2.894 \\
0.139 \\
1.861 \\
0.000 \\
0.071 \\
0.002\end{array}$ \\
\hline Total & 15.022 & 15.139 & 15.108 & 15.188 & 15.417 & 15.085 & 15.553 & 15.377 & 15.095 & 15.173 & 15.068 & 15.247 & 15.258 & 15.085 \\
\hline $\begin{array}{l}\mathrm{Mg} / \mathrm{Mg}+\mathrm{Fe}^{2+} \\
(\mathrm{Na}+\mathrm{K})_{\mathrm{A}}\end{array}$ & $\begin{array}{l}0.520 \\
0.000\end{array}$ & $\begin{array}{l}0.600 \\
0.117\end{array}$ & $\begin{array}{l}0.730 \\
0.000\end{array}$ & $\begin{array}{l}0.660 \\
0.115\end{array}$ & $\begin{array}{l}0.680 \\
0.360\end{array}$ & $\begin{array}{l}0.640 \\
0.004\end{array}$ & $\begin{array}{l}0.660 \\
0.553\end{array}$ & $\begin{array}{l}0.690 \\
0.342\end{array}$ & $\begin{array}{l}0.590 \\
0.074\end{array}$ & $\begin{array}{l}0.680 \\
0.006\end{array}$ & $\begin{array}{l}0.340 \\
0.068\end{array}$ & $\begin{array}{l}0.600 \\
0.254\end{array}$ & $\begin{array}{l}0.720 \\
0.015\end{array}$ & $\begin{array}{l}0.610 \\
0.073\end{array}$ \\
\hline
\end{tabular}

Notes: Textural sites of analyzed amphibole: inside veins (analyses V4083, V4103. B3107, V5169, B2187, V3064. B2186, and V4112); along the vein walls (analyses V4080, and V 1016); in alteration halo (analyses V5144, B3025, and B3037), and in the groundmass outside the halo (analysis B3069). Composition according to the Leake's (1978) nomenclature. $\mathrm{ACT}=$ actinolite: $\mathrm{Act}-\mathrm{HBL}=$ actinolitic hornblende: $\mathrm{Mg}-\mathrm{HBL}=$ magnesio-hornblende $\mathrm{CUMM}=$ cummingtonite $\mathrm{EDEN}=\mathrm{edenite} ; \mathrm{Fe}-\mathrm{ACT}=$ ferro-actinolite .

may be interpreted as mode 1 fractures (Pollard and Aydin, 1988) where opening displacement is perpendicular to the fracture surface. However, the occurrence of stepped veins (Sample 140-504B-213R$1,3-6 \mathrm{~cm}$, Piece 2) also suggests that fracture evolution may have been accompanied by shearing displacement. Mixed mode $1+$ mode 2 opening fractures may have formed with a resulting stair-shaped or tilted path (Pollard and Aydin, 1988). The fact that vein-filling minerals are not deformed in this stair-shaped vein supports this interpretation rather than syn-kinematic deformation affecting the vein after the filling process.

Other peculiar features of fracture propagation are represented in the studied samples by T-intersections between veins and by hookshaped or overlapping veins. T-type pattern is indicative of fracture propagation due to thermal contraction during rock cooling. This occurrence suggests that at least part of the veins may have been developed from cooling fractures as also inferred from the vein orientation data. In fact, one generation of veins, showing random fabric, may be related to local stress conditions dominated by contractional cooling (and/or high fluid pressure), rather than by a regional tectonic regime.

The arrangement of the vein-filling minerals suggests that vein evolution was probably controlled by different mechanisms. Most of the veins are filled with elongated amphibole crystals (fibers) which mainly represent syntaxial overgrowth on igneous clinopyroxene of the wallrock. The shape and crystallographic fabric of amphibole is strongly controlled by the orientation of clinopyroxene along the vein edges. This may explain the variable orientation of amphibole fibers inside the vein. In this case, the microstructural orientation of fibers is not very helpful for reconstructing the opening trajectories of the vein. Some veins are filled with stretched fibers connecting the opposite vein sides and are regularly inclined to the vein wall. This type of fibers may be formed by repeated de-localized fracturing of the vein during crack-seal process (Cox and Etheridge, 1983; Urai et al., 1993). Although crack-seal deformation probably represents one of the main process responsible for the formation of the veins studied, this cannot be supported by fluid inclusion criteria (Ramsay, 1980; Ramsay and Huber, 1983) because no fluid inclusions were observed inside amphibole at Hole 504B (D. Vanko, pers. comm., 1991).

A few sampled veins show evidence of reopening and filling with the same or different mineral species. In some chlorite + amphibolebearing veins the distribution of these two minerals within the vein is random. It is therefore difficult to discern whether chlorite and amphibole represent filling-minerals related to different crack-seal episodes or to the alteration of different igneous phases in the wallrock. In veins where crystals or fibers are distributed in a zoned pattern, (usually coarse-grained amphibole oriented with elongated shape perpendicular to the vein walls and fine-grained, foliated or bent amphibole in the vein center), crack-seal process may be characterized by two main opening stages. The symmetric distribution of fibers in the vein suggests that reopening stages are probably characterized by breaking of the fibers in the center of the vein rather than by detachment of fibers from the vein edges. Free growth of new fibers into the cracks is expected rather than syntaxial overgrowth of fibers on the wallrock minerals (Cox and Etheridge, 1983).

Deformation seems to have affected the studied veins in different ways. This is essentially inferred from the occurrence of bent crystals, tension gashes and breccias. It is important to note that in all cases, deformation is restricted to the veins and does not seem to affect the surrounding rock. We suggest that veins were essentially affected by coaxial deformation in the brittle domain. Crystal plasticity is indicated by the occurrence of bent crystals, although more detailed studies, such as TEM studies, could be needed to assert this. 

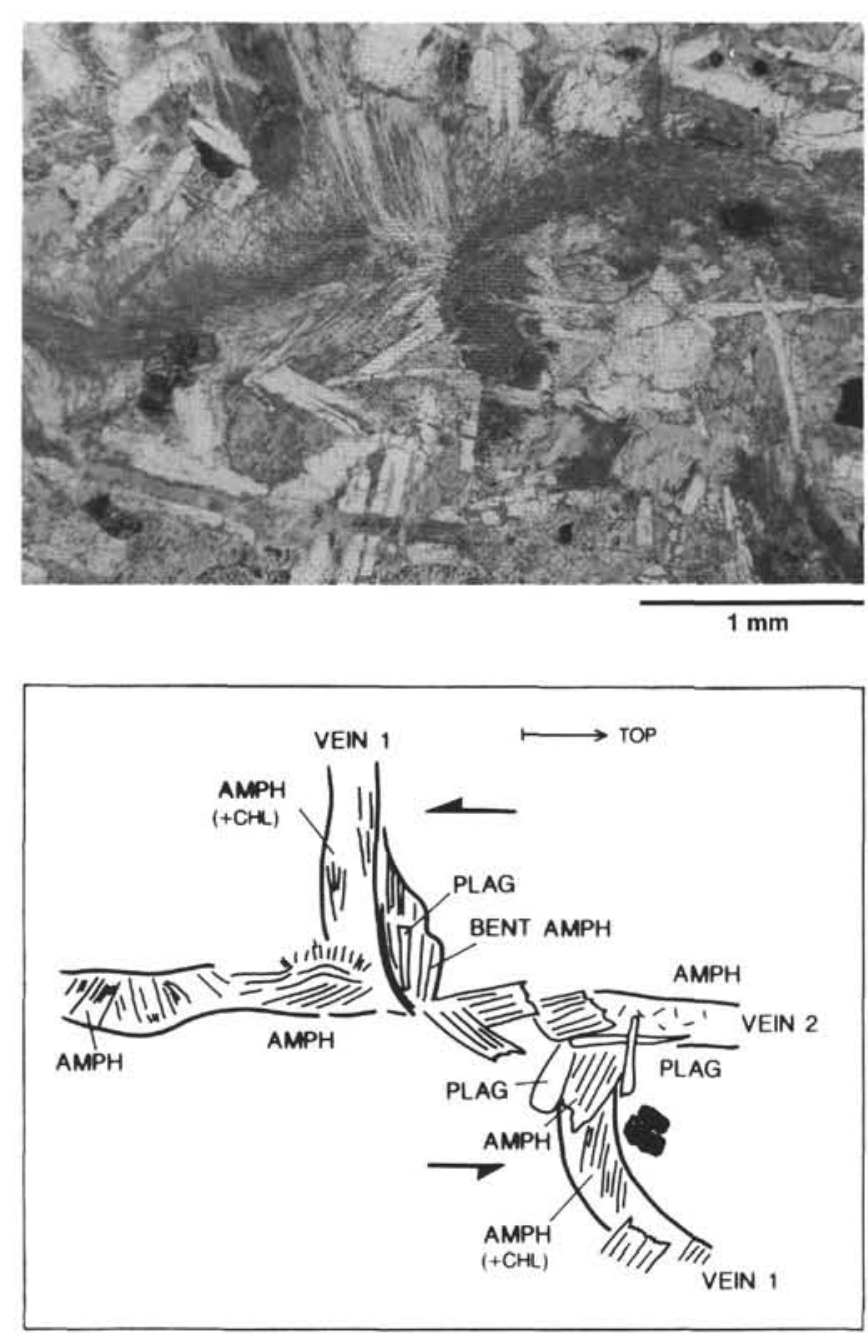

$0.07 \mathrm{~mm}$

Figure 4. Crosscutting relations with offset between veins (Sample 140-504B$186 \mathrm{R}-1,53-57 \mathrm{~cm}$, Piece 10). The top of thin section is indicated according to the core orientation. $\mathrm{AMPH}=$ amphibole PLAG $=$ plagioclase $; \mathrm{CHL}=$ chlorite; VEIN 1 = older vein cut by VEIN 2 .

Bending of the coarse-grained crystals is locally accompanied by crystal breaking. This deformation more probably affected crystals that were oriented with their long axes orthogonal, rather than subparallel to the vein walls. This process may be explained in terms of rock compaction in response to local stress variations or of vein collapse during crack-seal (Etheridge et al., 1984). According to this model, the crack collapse and consequent deformation of the precipitating minerals is induced by the fluid bleeding-off the fracture if pressure gradients (even local) between fractures and rock material exist.

Deformation by shear (mainly simple shear) in studied veins is indicated by: (1) offset in crosscutting veins accompanied by crystal deformation; (2) opening of pull-aparts within veins, and (3) opening of tension gashes in amphibole crystals filling the veins. Shear deformation seems to be limited to the vein domains because the texture of the wallrock appears isotropic and undeformed. In a few examples of oriented core pieces, where pull-apart and tension gashes occur in veins, the inferred shear sense suggests that displacement took place by a reverse faulting mechanism. The orientation of these veins is consistent with the measured set of shallowly dipping veins. By considering deformation effects from different scales, microscopic extensional features such as tension gashes and pull-aparts in veins can still be
Table 2. Representative analyses of secondary clinopyroxene filling the stepped-like vein from Sample 140-504B-213R-1, 3-6 cm (Piece 2).

\begin{tabular}{|c|c|c|c|c|}
\hline $\begin{array}{l}\text { Sample: } \\
\text { Analysis: } \\
\text { Occurrence: }\end{array}$ & $\begin{array}{c}213 \mathrm{R}-1 \\
3-6 \\
\mathrm{Cl} \\
\text { vein }\end{array}$ & $\begin{array}{c}213 R-1 \\
3-6 \\
C 2 \\
\text { vein }\end{array}$ & $\begin{array}{c}213 R-1 \\
3-6 \\
\text { C8 } \\
\text { vein }\end{array}$ & $\begin{array}{c}213 R-1 \\
3-6 \\
C 9 \\
\text { vein }\end{array}$ \\
\hline $\begin{array}{l}\mathrm{SiO}_{2} \\
\mathrm{TiO}_{2} \\
\mathrm{Al}_{2} \mathrm{O}_{3} \\
\mathrm{Cr}_{2} \mathrm{O}_{3} \\
\mathrm{FeO} \\
\mathrm{MnO} \\
\mathrm{MgO} \\
\mathrm{CaO} \\
\mathrm{NiO} \\
\mathrm{ZnO} \\
\mathrm{Na}_{2} \mathrm{O} \\
\mathrm{K}_{2} \mathrm{O} \\
\mathrm{Cl} \\
\mathrm{P}_{2} \mathrm{O}_{5}\end{array}$ & $\begin{array}{c}52.72 \\
0.2 \\
0.69 \\
0.01 \\
11.5 \\
0.32 \\
13.57 \\
21.72 \\
0.11 \\
0.01 \\
0.16 \\
0 \\
0 \\
0.25\end{array}$ & $\begin{array}{c}53.51 \\
0.17 \\
1.89 \\
0.02 \\
14.3 \\
0.38 \\
13.82 \\
16.11 \\
0 \\
0.08 \\
0.32 \\
0.03 \\
0 \\
0.22\end{array}$ & $\begin{array}{c}53.41 \\
0.17 \\
0.7 \\
0 \\
12.47 \\
0.4 \\
13.91 \\
18.75 \\
0 \\
0 \\
0.14 \\
0.01 \\
0.01 \\
0.25\end{array}$ & $\begin{array}{c}53.64 \\
0.01 \\
0.37 \\
0.02 \\
11.11 \\
0.28 \\
13.13 \\
22.61 \\
0 \\
0.12 \\
0.1 \\
0 \\
0 \\
0.34\end{array}$ \\
\hline Total & 101.01 & 100.63 & 99.97 & 101.39 \\
\hline $\begin{array}{l}\mathrm{Si} \\
\mathrm{Al}^{3+} \\
\mathrm{Fe}^{3+} \\
\mathrm{Fe}^{2+} \\
\mathrm{Mg} \\
\mathrm{Ca} \\
\mathrm{Na} \\
\mathrm{K} \\
\mathrm{Ti} \\
\mathrm{Mn} \\
\mathrm{Cl} \\
\mathrm{Cr} \\
\mathrm{Ni} \\
\mathrm{Zn}\end{array}$ & $\begin{array}{l}1.962 \\
0.03 \\
0.046 \\
0.312 \\
0.753 \\
0.866 \\
0.012 \\
0 \\
0.006 \\
0.01 \\
0 \\
0 \\
0.003 \\
0\end{array}$ & $\begin{array}{l}1.992 \\
0.083 \\
0 \\
0.445 \\
0.767 \\
0.643 \\
0.023 \\
0.001 \\
0.005 \\
0.012 \\
0 \\
0.001 \\
0 \\
0.002\end{array}$ & $\begin{array}{l}2.002 \\
0.031 \\
0 \\
0.391 \\
0.777 \\
0.753 \\
0.01 \\
0 \\
0.005 \\
0.013 \\
0.001 \\
0 \\
0 \\
0\end{array}$ & $\begin{array}{l}1.992 \\
0.016 \\
0.006 \\
0.339 \\
0.727 \\
0.9 \\
0.007 \\
0 \\
0 \\
0.009 \\
0 \\
0.001 \\
0 \\
0.003\end{array}$ \\
\hline Total & 4 & 3.974 & 3.983 & 4 \\
\hline $\begin{array}{l}100 \mathrm{Mg} / \mathrm{Mg}+\mathrm{Fe}^{2+} \\
\text { Enstatite \% } \\
\text { Ferrosilite \% } \\
\text { Wollastonite \% }\end{array}$ & $\begin{array}{l}70.706 \\
38.992 \\
16.155 \\
44.854\end{array}$ & $\begin{array}{l}63.273 \\
41.352 \\
24.003 \\
34.644\end{array}$ & $\begin{array}{l}66.538 \\
40.458 \\
20.347 \\
39.195\end{array}$ & $\begin{array}{l}68.181 \\
36.978 \\
17.257 \\
45.765\end{array}$ \\
\hline
\end{tabular}

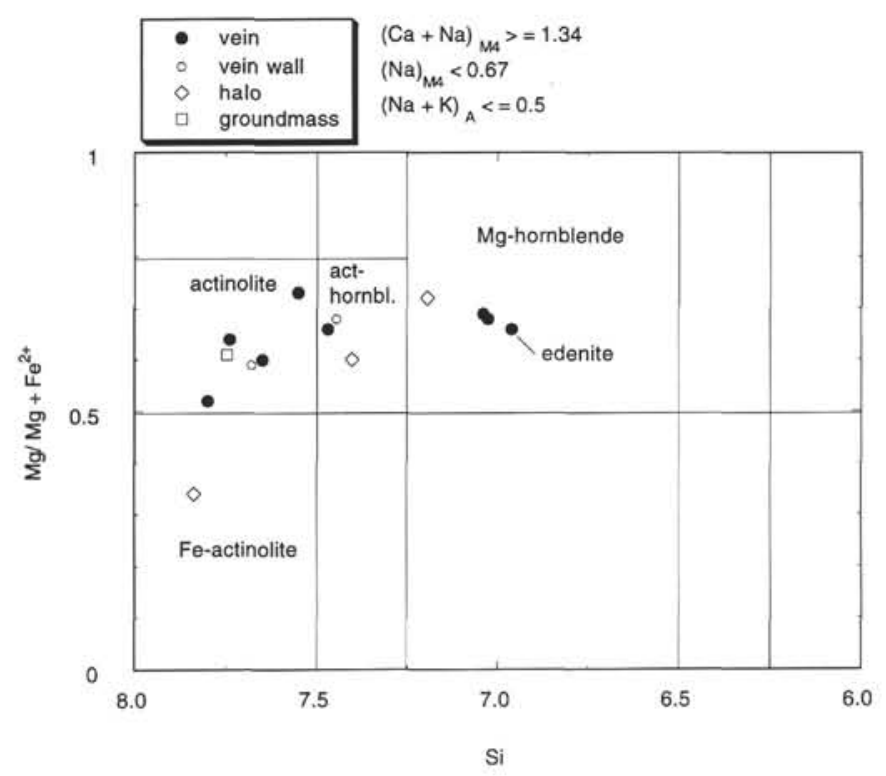

Figure 5. $\mathrm{Mg}$ number $\left(\mathrm{Mg} / \mathrm{Mg}+\mathrm{Fe}^{2+}\right)$ vs. $\mathrm{Si}$ (atoms per formula unit) of amphiboles listed in Table 1. Edenite (analysis B2186 in Table 1) is reported for comparison, although it has $(\mathrm{Na}+\mathrm{K})>0.5$. Nomenclature after Leake (1978). 
Table 3. Representative analyses of zeolites from Hole 504B, Leg 140.

\begin{tabular}{|c|c|c|c|c|c|c|c|c|c|}
\hline $\begin{array}{l}\text { Sample: } \\
\text { Analysis: } \\
\text { Occurrence: }\end{array}$ & $\begin{array}{c}186 R-1, \\
57-60 \\
\text { LAUM } \\
\text { V4096 } \\
\text { tension } \\
\text { gashes }\end{array}$ & $\begin{array}{l}186 R-1, \\
57-60 \\
\text { LAUM } \\
\text { V4097 } \\
\text { tension } \\
\text { gashes }\end{array}$ & $\begin{array}{c}\text { 186R-1, } \\
57-60 \\
\text { LAUM } \\
\text { V4104 } \\
\text { tension } \\
\text { gashes }\end{array}$ & $\begin{array}{c}\text { 186R-I, } \\
57-60 \\
\text { LAUM } \\
\text { V4106 } \\
\text { tension } \\
\text { gashes }\end{array}$ & $\begin{array}{c}\text { I86R-I. } \\
57-60 \\
\text { LAUM } \\
\text { V4108 } \\
\text { interst. }\end{array}$ & $\begin{array}{l}\text { I86R-1. } \\
57-60 \\
\text { LAUM } \\
\text { V411I } \\
\text { interst. }\end{array}$ & $\begin{array}{l}\text { I89R-1, } \\
106-110 \\
\text { HEUL } \\
\text { V5117 } \\
\text { tension } \\
\text { gashes }\end{array}$ & $\begin{array}{l}189 \mathrm{R}-1, \\
106-110 \\
\text { HEUL } \\
\text { V } 5118 \\
\text { tension } \\
\text { gashes }\end{array}$ & $\begin{array}{l}\text { 189R-1, } \\
\text { 106-110 } \\
\text { HEUL } \\
\text { V5I119 } \\
\text { tension } \\
\text { gashes }\end{array}$ \\
\hline $\begin{array}{l}\mathrm{SiO}_{2} \\
\mathrm{TiO}_{2} \\
\mathrm{Al}_{2} \mathrm{O}_{3} \\
\mathrm{Cr}_{2} \mathrm{O}_{3} \\
\mathrm{FeO} \\
\mathrm{MnO} \\
\mathrm{MgO} \\
\mathrm{NiO} \\
\mathrm{CaO} \\
\mathrm{Na}_{2} \mathrm{O} \\
\mathrm{K}_{2} \mathrm{O} \\
\mathrm{ZnO}_{\mathrm{Cl}}\end{array}$ & $\begin{array}{r}55.21 \\
0.01 \\
21.37 \\
0.01 \\
0.16 \\
0.05 \\
0.00 \\
0.02 \\
10.93 \\
0.08 \\
0.02 \\
0.00 \\
0.00\end{array}$ & $\begin{array}{r}54.34 \\
0.05 \\
21.14 \\
0.01 \\
0.12 \\
0.06 \\
0.00 \\
0.09 \\
11.09 \\
0.22 \\
0.06 \\
0.00 \\
0.02\end{array}$ & $\begin{array}{r}55.65 \\
0.00 \\
20.91 \\
0.00 \\
0.17 \\
0.00 \\
0.00 \\
0.03 \\
10.70 \\
0.03 \\
0.07 \\
0.00 \\
0.02\end{array}$ & $\begin{array}{r}55.71 \\
0.01 \\
21.62 \\
0.00 \\
0.30 \\
0.05 \\
0.02 \\
0.01 \\
10.77 \\
0.10 \\
0.06 \\
0.05 \\
0.01\end{array}$ & $\begin{array}{r}55.91 \\
0.02 \\
21.09 \\
0.00 \\
0.18 \\
0.02 \\
0.00 \\
0.01 \\
11.12 \\
0.12 \\
0.10 \\
0.03 \\
0.04\end{array}$ & $\begin{array}{r}55.54 \\
0.00 \\
21.28 \\
0.00 \\
0.25 \\
0.03 \\
0.28 \\
0.06 \\
11.14 \\
0.16 \\
0.03 \\
0.00 \\
0.01\end{array}$ & $\begin{array}{r}59.97 \\
0.02 \\
17.41 \\
0.00 \\
0.17 \\
0.00 \\
0.02 \\
0.04 \\
8.46 \\
0.05 \\
0.06 \\
0.07 \\
0.00\end{array}$ & $\begin{array}{r}59.38 \\
0.00 \\
16.12 \\
0.03 \\
0.19 \\
0.03 \\
0.05 \\
0.00 \\
8.44 \\
0.08 \\
0.00 \\
0.06 \\
0.04\end{array}$ & $\begin{array}{r}58.57 \\
0.00 \\
17.48 \\
0.02 \\
0.22 \\
0.00 \\
0.03 \\
0.03 \\
8.74 \\
0.06 \\
0.02 \\
0.06 \\
0.00\end{array}$ \\
\hline Total & 87.86 & 87.20 & 87.58 & 88.71 & 88.64 & 88.78 & 86.27 & 84.42 & 85.23 \\
\hline $\begin{array}{l}\mathrm{Si} \\
\mathrm{Ti} \\
\mathrm{Al} \\
\mathrm{Cr}^{2+} \\
\mathrm{Fe}^{2+} \text { total } \\
\mathrm{Mn} \\
\mathrm{Mg} \\
\mathrm{Ni} \\
\mathrm{Ca} \\
\mathrm{Na} \\
\mathrm{K} \\
\mathrm{Zn} \\
\mathrm{Cl}\end{array}$ & $\begin{array}{l}4.135 \\
0.001 \\
1.887 \\
0.001 \\
0.010 \\
0.003 \\
0.000 \\
0.001 \\
0.877 \\
0.012 \\
0.002 \\
0.000 \\
0.000\end{array}$ & $\begin{array}{l}4.114 \\
0.003 \\
1.887 \\
0.001 \\
0.008 \\
0.004 \\
0.000 \\
0.005 \\
0.900 \\
0.032 \\
0.006 \\
0.000 \\
0.003\end{array}$ & $\begin{array}{l}4.174 \\
0.000 \\
1.849 \\
0.000 \\
0.011 \\
0.000 \\
0.000 \\
0.002 \\
0.860 \\
0.004 \\
0.007 \\
0.000 \\
0.003\end{array}$ & $\begin{array}{l}4.134 \\
0.001 \\
1.892 \\
0.000 \\
0.019 \\
0.003 \\
0.002 \\
0.001 \\
0.856 \\
0.014 \\
0.006 \\
0.003 \\
0.001\end{array}$ & $\begin{array}{l}4.156 \\
0.001 \\
1.848 \\
0.000 \\
0.011 \\
0.001 \\
0.000 \\
0.001 \\
0.886 \\
0.017 \\
0.009 \\
0.002 \\
0.005\end{array}$ & $\begin{array}{l}4.126 \\
0.000 \\
1.864 \\
0.000 \\
0.016 \\
0.002 \\
0.031 \\
0.004 \\
0.887 \\
0.023 \\
0.003 \\
0.000 \\
0.001\end{array}$ & $\begin{array}{l}6.739 \\
0.002 \\
2.307 \\
0.000 \\
0.016 \\
0.000 \\
0.003 \\
0.004 \\
1.019 \\
0.011 \\
0.009 \\
0.006 \\
0.000\end{array}$ & $\begin{array}{l}6.820 \\
0.000 \\
2.183 \\
0.003 \\
0.018 \\
0.003 \\
0.009 \\
0.000 \\
1.039 \\
0.018 \\
0.000 \\
0.005 \\
0.008\end{array}$ & $\begin{array}{l}6.680 \\
0.000 \\
2.351 \\
0.002 \\
0.021 \\
0.000 \\
0.005 \\
0.003 \\
1.068 \\
0.013 \\
0.003 \\
0.005 \\
0.000\end{array}$ \\
\hline Total & 6.928 & 6.959 & 6.907 & 6.930 & 6.932 & 6.955 & 10.115 & 10.097 & 10.151 \\
\hline
\end{tabular}

Note: Zeolite filling tension gashes $=$ analyses V4096, V4097, V4104, V4106, V5117, V5118, and V51 19; filling interstitial spaces in vein and associated with amphibole acicular crystals = analyses V4108 and V4111.

compatible with a (localized?) compressive regime as suggested by reverse microfaulting. Evidence of a compressive regime is suggested by the shallowly dipping set of veins that were measured during Leg 140. A compressional stress state has been inferred at Hole 504B from the occurrence of breakouts at depths below $700 \mathrm{mbsf}$, indicating a maximum horizontal compressive stress roughly perpendicular to the ridge axis (Moos and Zoback, 1990). Results from breakouts are also consistent with the state of stress inferred from borehole televiewer (BHTV) logs at Hole 504B (Morin et al., 1989, 1990) and from compressional (strike-slip and reverse faulting) earthquake focal mechanisms in young oceanic crust (Bergman and Solomon, 1984; Bratt et al., 1985). The earthquake focal mechanisms reveal that reverse faulting predominates at shallow depths and that at greater depths, strike-slip and normal faulting become more common. The compressive crustal stresses in young oceanic crust (younger than 15 m.y.) have been interpreted as due to thermoelastic effects of plate cooling more than to plate-driving forces (Bratt et al., 1985; Moos and Zoback, 1990).

Brittle deformation in the studied rocks is also pointed out by the occurrence of breccia zones associated with veins. These breccia zones may be interpreted in terms of cataclasis or, alternatively, of hydraulic fracturing accompanying or following the veining process. Hydraulic fracturing would require that fluid pressure $\left(P_{f}\right)$ locally exceeds the confining pressure.

\section{Mineralogy}

Mineral chemistry data obtained from vein-filling minerals, coupled with microstructural observations in veins, are helpful for understanding the evolution of rock alteration in relation to deformation. Most of the veins are filled with amphibole. Amphibole analyses carried out in distinct textural sites within veins and in the host rock suggest that: (1) veins are mostly filled with actinolite; (2) in alteration halos around veins, actinolitic hornblende and $\mathrm{Mg}$-hornblende prevail; (3) in the groundmass, away from halos, actinolite is the main amphibole composition; (4) multiply opened veins are usually filled with hornblende along the vein walls and with actinolite in the vein center. These observations suggest that: (1) according to the amphibole composition, namely the Al IV and Ti contents (Liou et al., 1974; Blundy and Holland, 1990), amphibole occurring at the vein edges and in the halos around veins could have formed under relatively higher temperature conditions, during early hydrothermal alteration within incipient fractures. Reactions were restricted to the veins and halos because not enough fluid was available, or because rock permeability was low, or because the fluid circulation was too short-lived (see also Laverne et al., this volume); and (2) veins probably recorded higher temperature conditions of the circulating fluids along the vein walls and progressively lower temperature conditions in the vein center, due to subsequent cooling of fluids. Otherwise, we have to take into account that amphibole composition probably depends on the microstructural site in which it grows (e.g., vein, wallrock close to the vein or away from the vein) because igneous minerals of the wallrock can be involved during metamorphic reactions. For this reason, interpretations of temperature conditions should be given with caution.

Fluid evolution under progressively lower temperatures is inferred by considering the occurrence of zeolites (the upper thermal stability of laumontite is $230^{\circ} \mathrm{C}$; Liou, 1971) filling interstitial spaces or latestage tension gashes in actinolite and chlorite-filled veins. A similar zoned pattern has been observed in amygdules containing chlorite and actinolite in the margins and epidote, quartz, or laumontite-filled cores (Dick, Erzinger, Stokking, et al., 1992).

Mineral assemblages described in the veins are consistent with the alteration history inferred for the transition zone and dikes at Hole 504B (Alt et al., 1986, 1989, and this volume). Vein-filling minerals of different metamorphic facies have been observed, consistently with the alteration evolution occurring under decreasing temperatures, when the crust moved away from the spreading axis. However, 


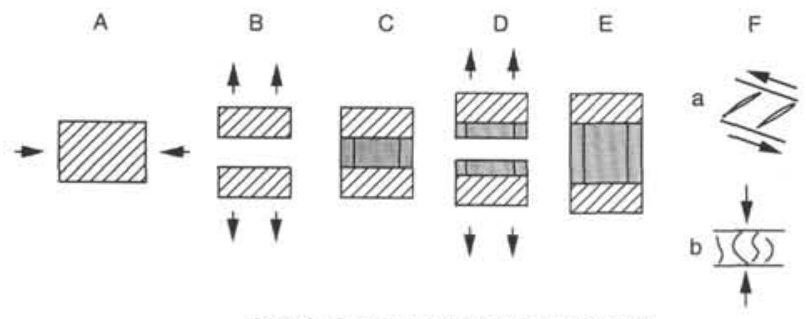

B1
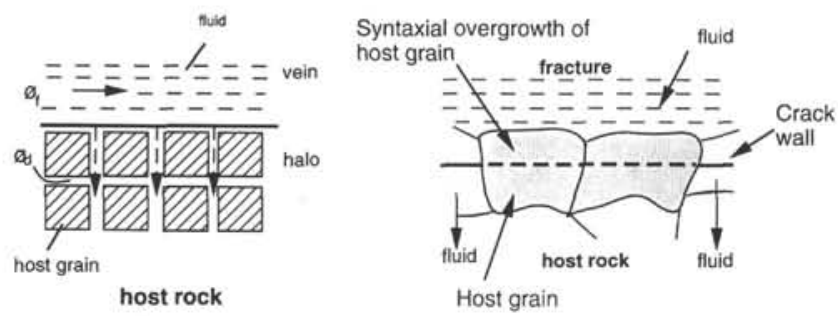

Figure 6. Cartoon representing a possible schematic vein formation mechanism (see text for explanation). $\emptyset_{\mathrm{f}}$ and $\emptyset_{\mathrm{d}}=$ flow porosity and diffusion porosity, respectively (after Norton and Knapp, 1977).

detailed microstructural observations, in connection with mineralogy, have shown that alteration is heterogeneous at the microscopic scale. The composition of secondary mineral products strongly depends on the microstructural site of the rock, because it can be affected by the primary phases that are involved by metamorphic reactions. If this is the case, it can be difficult to characterize the hydrothermal alteration at a larger scale.

\section{SUMMARY}

According to the microstructural features and mineralogy of the studied veins, the following schematic sequence of vein formation mechanism may be proposed (Fig. 6):

1. Fracturing of rock (pure extension fractures, stage A, in Fig. 6) due mainly to the cooling and/or to the regional stress field. The former process is probably responsible for the randomly oriented vein set, and the regional stress field (compressive?) may be responsible for the generation of shallowly dipping veins.

2. Circulation of relatively high-temperature fluids inside cracks, and subsequent fracture filling by secondary clinopyroxene and amphibole (crack-seal, stage B, in Fig. 6). Rock porosity (mainly diffusion porosity) may allow fluid percolation through the wallrock, followed by the formation of alteration halos around fractures where actinolitic hornblende and $\mathrm{Mg}$-hornblende crystallized (stage B1, in Fig. 6). Hornblende may also grow along vein walls as syntaxial overgrowth on igneous clinopyroxene in the wallrock (stage B2).

3. Crack-seal process ensuring the re-opening of veins and subsequent filling by mainly greenschist facies mineral assemblage (actinolite, chlorite, quartz, epidote?; stages C, D, and E, in Fig. 6).

4. Shear deformation restricted to veins (stage F-a, in Fig. 6). This is indicated by the presence of tension cracks, tension gashes, and pull-aparts in veins and offsets between veins. Shearing may be partly produced by injection of dikes. Vein orientation and shear sense indicate that reverse microfaulting may occur locally.

5 . Further filling of veins by late-stage, lower temperature (about $250^{\circ} \mathrm{C}$ and lower) minerals (e.g., laumontite and heulandite).

6. Deformation of the vein-filling minerals by local compaction due to local stress variation, or by collapsing of the rock during fluid circulation in cracks, and precipitation of material in solution (stage F-b, in Fig. 6).

\section{ACKNOWLEDGMENTS}

We are grateful to all the Leg 140 participants for the constructive discussions on Hole 504B during the cruise. All data were obtained thanks to the strong effort of the drilling team during fishing operations. Catherine Mével, Chris J. MacLeod, and Susan M. Agar greatly improved this manuscript with their careful review and suggestions. This work was supported by CNR funds to P.T.

\section{REFERENCES $*$}

Adamson, A.C., 1984. Hydrothermal petrology in the Costa Rica Rift [Ph.D. thesis]. Univ. Newcastle-upon-Tyne, UK.

, 1985. Basement lithostratigraphy, Deep Sea Drilling Project Hole 504B. In Anderson, R.N., Honnorez, J., Becker, K., et al., Init. Repts. DSDP, 83: Washington (U.S. Govt. Printing Office), 121-127.

Agar, S.M., 1990. Fracture evolution in the upper ocean crust: evidence from DSDP Hole 504B. In Knipe, R.J., and Rutter, E.H. (Eds.), Deformation Mechanisms, Rheology and Tectonics. Geol. Soc. Spec. Publ. London, 54:41-50.

-1991 . Microstructural evolution of a deformation zone in the upper ocean crust: evidence from DSDP Hole 504B. J. Geodyn., 13:119-140.

Alt, J.C., Anderson, T.F., Bonnell, L., and Muehlenbachs, K., 1989. Mineralogy, chemistry, and stable isotopic compositions of hydrothermally altered sheeted dikes: ODP Hole 504B, Leg 111. In Becker, K., Sakai, H., et al., Proc. ODP, Sci. Results, 111: College Station, TX (Ocean Drilling Program), $27-40$.

Alt, J.C., Honnorez, J., Laverne, C., and Emmermann, R., 1986. Hydrothermal alteration of a $1 \mathrm{~km}$ section through the upper oceanic crust, Deep Sea Drilling Project Hole 504B: mineralogy, chemistry, and evolution of seawater-basalt interactions. J. Geophys. Res., 91:10309-10335.

Alt, J.C., Laverne, C., and Muehlenbachs, K., 1985. Alteration of the upper oceanic crust: mineralogy and processes in Deep Sea Drilling Project Hole 504B, Leg 83. In Anderson, R.N., Honnorez, J., Becker, K., et al., Init. Repts. DSDP, 83: Washington (U.S. Govt. Printing Office), 217-247.

Anderson, R.N., Honnorez, J., Becker, K., et al., 1985. Init. Repts. DSDP, 83: Washington (U.S. Govt. Printing Office).

Becker, K., Sakai, H., et al., 1988. Proc. ODP, Init. Repts., 111: College Station, TX (Ocean Drilling Program).

Bergman, E.A., and Solomon, S.C., 1984. Source mechanisms of earthquakes near mid-ocean ridges from body waveform inversion: implications for the early evolution of oceanic lithosphere. J. Geophys. Res., 89:11415-11441.

Blundy, J.D., and Holland, T.J.B., 1990. Calcic amphibole equilibria and a new amphibole-plagioclase geothermometer. Contrib. Mineral. Petrol., 104:208-224.

Bratt, S.R., Bergman, E.A., and Solomon, S.C., 1985. Thermoelastic stress: how important as a cause of earthquakes in young oceanic lithosphere? $J$. Geophys. Res., 90:10249-10260.

Cann, J.R., Langseth, M.G., Honnorez, J., Von Herzen, R.P., White, S.M., et al., 1983. Init. Repts. DSDP, 69: Washington (U.S. Govt. Printing Office).

Castelli, D., 1988. Chloropotassium ferro-pargasite from Sesia-Lanzo marbles (Western Italian Alps): a record of highly saline fluids. Rend. Soc. Ital. Mineral. Petrol., 43:129-138.

Cox, S.F., and Etheridge, M.A., 1983. Crack-seal fibre growth mechanisms and their significance in the development of oriented layer silicate microstructures. Tectonophysics, 92:147-170.

Dick, H.J.B., Erzinger, J., Stokking, L.B., et al., 1992. Proc. ODP, Init. Repts., 140: College Station, TX (Ocean Drilling Program).

Droop, G.T.R., 1987. A general equation for estimating $\mathrm{Fe}^{3+}$ concentrations in ferromagnesian silicates and oxides from microprobe analyses, using stoichiometric criteria. Mineral. Mag., 51:431-435.

Durney, D.W., and Ramsay, J.G., 1973. Incremental strains measured by syntectonic crystal growth. In De Jong, K.A., and Scholten, R. (Eds.), Gravity and Tectonics: New York (Wiley), 67-96.

Enami, M., Liou, J.G., and Bird, D.K., 1992. Cl-amphibole in the Salton Sea geothermal system, California. Can. Mineral., 30:1077-1092.

\footnotetext{
Abbreviations for names of organizations and publications in ODP reference lists follow the style given in Chemical Abstracts Service Source Index (published by American Chemical Society).
} 
Etheridge, M.A., Wall, V.J., Cox, S.F., and Vernon, R.H., 1984. High fluid pressures during regional metamorphism and deformation: implications for mass transport and deformation mechanisms. J. Geophys. Res., 89:4344-4358.

Gillis, K.M., Thompson, G., and Kelley, D.S., 1993. A view of the lower crustal component of hydrothermal systems at the Mid-Atlantic Ridge. $J$. Geophys. Res., 98:19597-19619.

Gulyaeva, T.Y., Gorelikova, N.V., and Karabstov, A.A., 1986. High potassiumchlorine-bearing hastingsites in skarns from Primorye, far east USSR. Mineral. Mag., 50:724-728.

Hey, R., Johnson, L., and Lowrie, A., 1977. Recent plate motion in the Galapagos Area. Geol. Soc. Am. Bull., 88:1385-1403.

Hobart, M.A., Langseth, M.G., and Anderson, R.N., 1985. A geothermal and geophysical survey on the south flank of the Costa Rica Rift: Sites 504 and 505. In Anderson, R.N., Honnorez, J., et al., Init. Repts. DSDP, 83: Washington (U.S. Govt. Printing Office), 379-404.

Kempton, P.D., Autio, L.K., Rhodes, J.M., Holdaway, M.J., Dungan, M.A., and Johnson, P., 1985. Petrology of basalts from Hole 504B, Deep Sea Drilling Project, Leg 83. In Anderson, R.N., Honnorez, J., Becker, K., et al., Init. Repts. DSDP, 83: Washington (U.S. Govt. Printing Office), 129-164.

Klitgord, K.D., Huestis, S.P., Mudie, J.D., and Parker, R.L., 1975. An analysis of near-bottom magnetic anomalies, sea-floor spreading and the magnetized layer. Geophys. J. R. Astron. Soc., 43:387-424.

Leake, B.E., 1978. Nomenclature of amphiboles. Can. Mineral., 16:501-520.

Liou, J.G., 1971. Stilbite-laumontite equilibrium. Contrib. Mineral. Petrol., $31: 171-177$

Liou, J.G., Kuniyoshi, S., and Ito, K., 1974. Experimental studies of the phase relations between greenschist and amphibolite in a basaltic system. Am. J. Sci., 274:613-632.

Mével, C., 1984. Le métamorphisme dans la croute océanique [Ph.D. thesis]. Univ. Pierre et Marie Curie, Paris.

Moos, D., and Zoback, M.D., 1990. Utilization of observations of well bore failure to constrain the orientation and magnitude of crustal stresses: application to continental, Deep Sea Drilling Project, and Ocean Drilling Program boreholes. J. Geophys. Res., 95:9305-9325.

Morin, R.H., Anderson, R.N., and Barton, C.A., 1989. Analysis and interpretation of the borehole televiewer log: information on the state of stress and the lithostratigraphy at Hole 504B. $m$ Becker, K., Sakai, H., et al., Proc. ODP, Sci. Results, 111: College Station, TX (Ocean Drilling Program), 109-118.

Morin, R.H., Newmark, R.L., Barton, C.A., and Anderson, R.N., 1990. State of lithospheric stress and borehole stability at Deep Sea Drilling Project Site 504B, eastern Equatorial Pacific. J. Geophys. Res., 95:9293-9303.

Morrison, J., 1991. Compositional constraints on the incorporation of $\mathrm{Cl}$ into amphiboles. Am. Mineral., 76:1920-1930.
Newmark, R.L., Anderson, R.N., Moos, D., and Zoback, M.D., 1985a. Sonic and ultrasonic logging of Hole 504B and its implications for the structure, porosity, and stress regime of the upper $1 \mathrm{~km}$ of the oceanic crust. In Anderson, R.N.. Honnorez, J., Becker, K., et al., Init. Repts. DSDP, 83: Washington (U.S. Govt. Printing Office), 479-510.

Newmark, R.L., Zoback, M.D., and Anderson, R.N., 1985b. Orientation of in situ stresses near the Costa Rica Rift and Peru-Chile Trench, Deep Sea Drilling Project Hole 504B. In Anderson, R.N., Honnorez, J., Becker, K., et al., Init. Repts. DSDP, 83: Washington (U.S. Govt. Printing Office), 5II-514.

Norton, D., and Knapp, R., 1977. Transport phenomena in hydrothermal system: the nature of porosity. Am. J. Sci., 277:913-936.

Oberti, R., Ungaretti, L., Cannillo, E., and Hawthorne, F.C., 1993. The mechanism of $\mathrm{Cl}$ incorporation in amphibole. Am. Mineral., 78:746-752.

Papike, J.J., Cameron, K.L., and Baldwin, K., 1974. Amphiboles and pyroxenes: characterization of other than quadrilateral components and estimates of ferric iron from microprobe data. Geol. Soc. Am. Abstr. Progr., 6:1053-1054.

Pezard, P.A., and Anderson, R.N., 1989. Morphology and alteration of the upper oceanic crust from in-situ electrical experiments in DSDP/ODP Hole 504B. In Becker, K., Sakai, H., et al., Proc. ODP, Sci. Results, 111: College Station, TX (Ocean Drilling Program), 133-146.

Pollard, D.D., and Aydin, A., 1988. Progress in understanding jointing over the past century, Geol. Soc. Am. Bull., 100:1181-1204.

Ramsay, J.G., 1980. The crack-seal mechanism of rock deformation. Nature, 284:135-139.

Ramsay, J.G., and Huber, M., 1983. The Techniques of Modern Structural Geology (Vol. 1): Strain Analysis: London (Academic Press).

Rock, N.M.S., and Carroll, G.W., 1990. MINTAB: a general-purpose mineral recalculation and tabulation program for Macintosh microcomputers. Am. Mineral., 75:424-430.

Stakes, D., Mével, C., Cannat, M., and Chaput, T., 1991. Metamorphic stratigraphy of Hole 735B. In Von Herzen, R.P., Robinson, P.T., et al., Proc. ODP, Sci. Results, 118: College Station, TX (Ocean Drilling Program), 153-180.

Suwa, K., Enami, M., and Horiuchi, T., 1987. Chlorine-rich potassium hastingsite from West Ongul Island, Lutzow-Holm Bay, East Antarctica. Mineral. Mag., 51:709-714.

Urai, J.L., Williams, P.F., and van Roermund, H.L.M., 1993. Kinematics of crystal growth in syntectonic fibrous veins. J. Struct. Geol., 13:823-836.

Vanko, D.A., 1986. High-chlorine amphiboles from oceanic rocks: product of highly saline hydrothermal fluids? Am. Mineral., 71:51-59.

\section{Date of initial receipt: 17 May 1993 \\ Date of acceptance: 3 May 1994 \\ Ms 137/140SR-026}




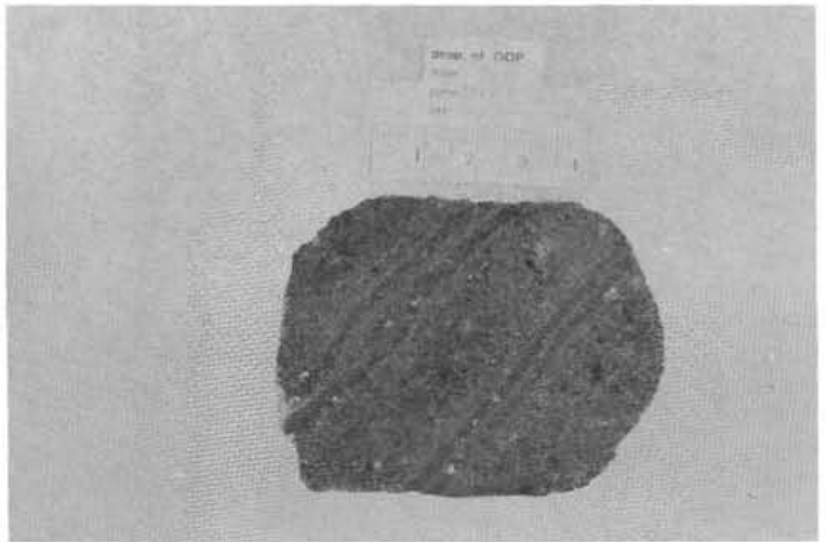

1

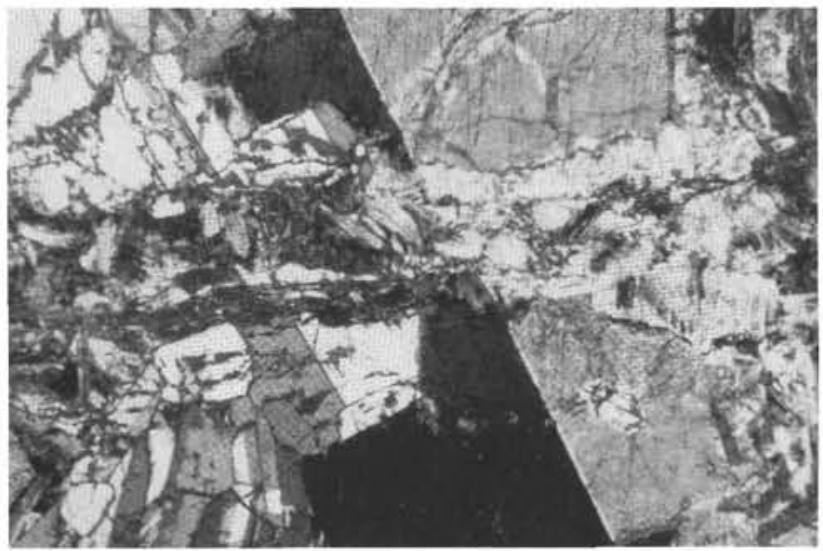

3

$0.5 \mathrm{~mm}$

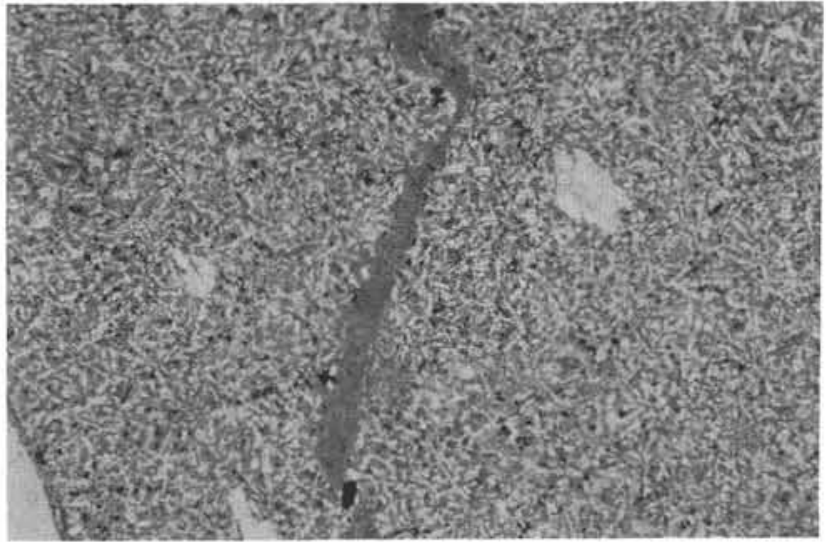

2

$2 \mathrm{~mm}$

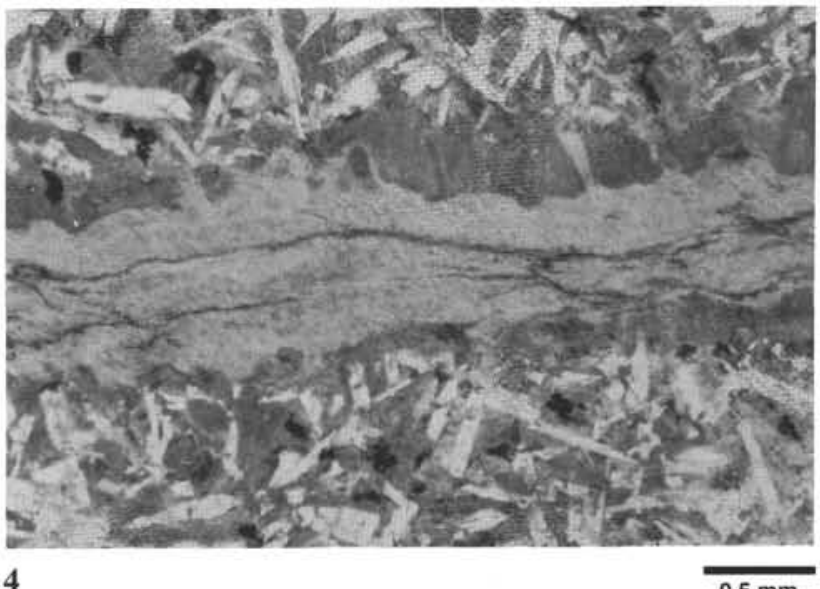

$0.5 \mathrm{~mm}$

Plate 1. Hand specimen photo and photomicrographs of vein-bearing diabases. 1. Amphibole-filled veins in diabase (Sample 140-504B-190R-1, 74-81 cm). Complex alteration halos are developed around veins. One vein is derived by two overlapping veins that coalesced. 2 . Stepped-like vein filled with fine-grained clinopyroxene (Sample 140-504B-213R-1, 3-6 cm, Piece 2). Plane light. 3. Amphibole-filled vein crosscutting clinopyroxene (twinned) + plagioclase clot (Sample 140-504B-186R-1,21-23 cm, Piece 5). Vein walls consist of syntaxial overgrowth of amphibole on clinopyroxene; vein center is filled with amphibole clasts. Crossed nicols. 4. Zoned pattern in amphibole vein (detail of Pl. 2, Fig. 4.). Along the vein edges, amphibole fibers are orthogonal to the vein walls (dark gray). Fine-grained amphibole in the vein center (light gray) is associated with opaque seams (Sample 140-504B-197R-1, 99-101 cm, Piece 22). Plane light. 


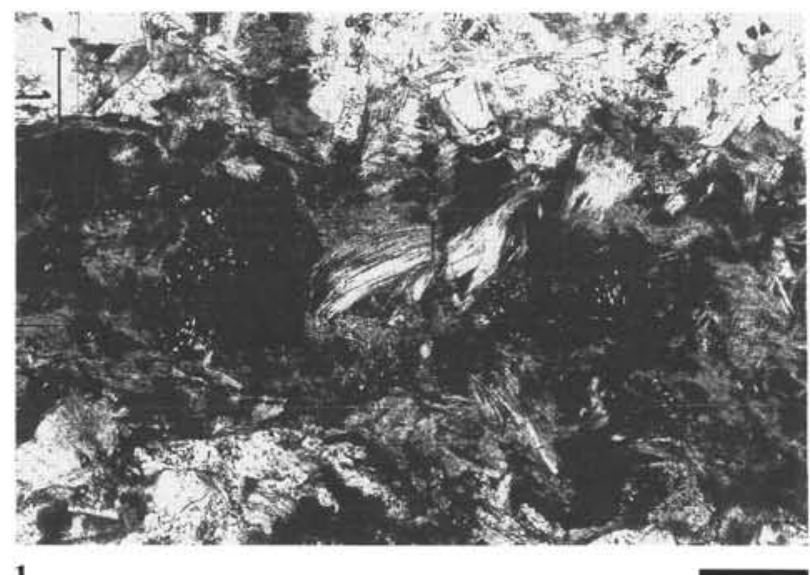

1

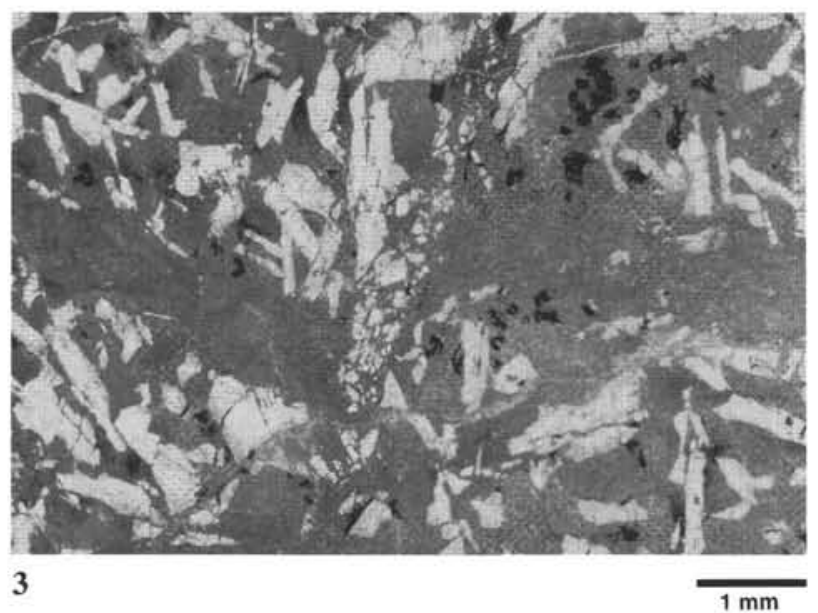

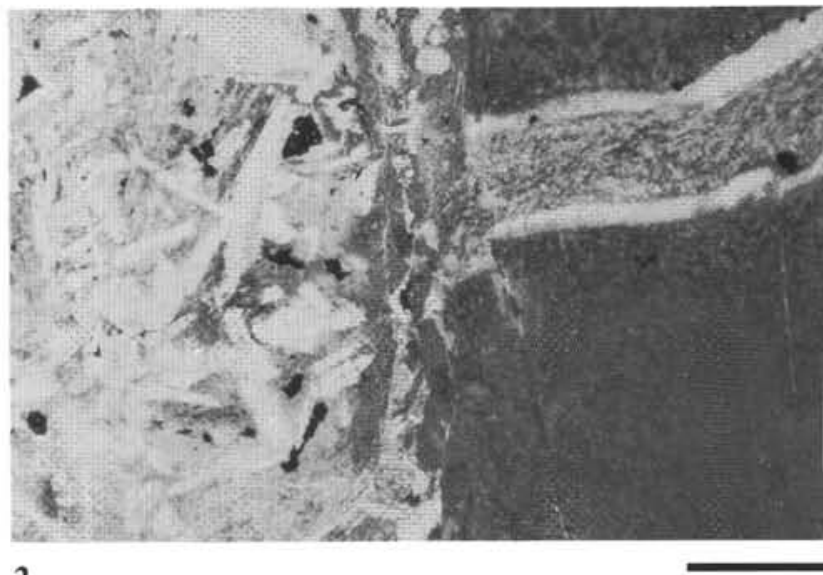

2

$1 \mathrm{~mm}$

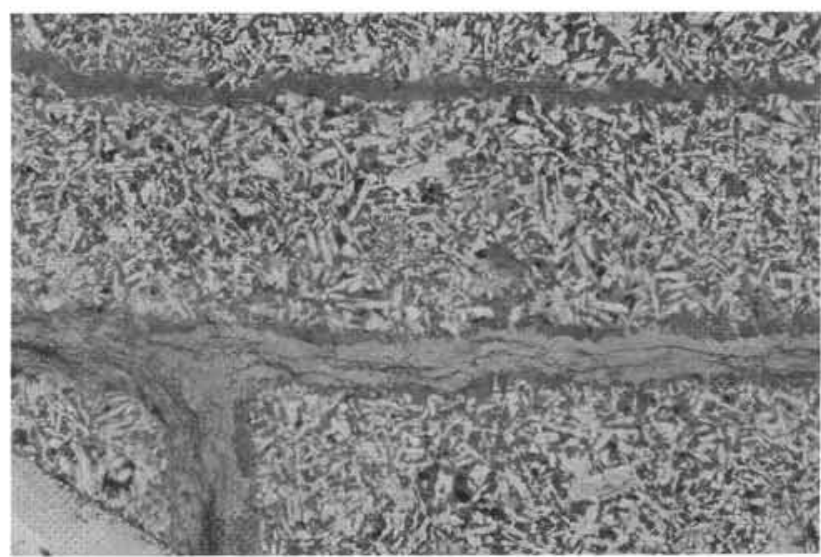

4

$0.25 \mathrm{~mm}$

Plate 2. Photomicrographs of veins in diabases. 1. Bent amphibole crystals (white in the black field) in amphibole-filled vein (Sample 140-504B-189R-1, 105-106 cm, Piece 21B). Crossed nicols. 2. Contact between diabase (left) and chilled margin (dark, on the right). Shear deformation is marked along the contact by the offset of a vein filled with amphibole and by breccia zone. Plane light. 3. Microbreccia zone (in the center of the photo) offsetting an amphibole-filled vein (Sample 140-504B-22IR-1, 11-15 cm. Piece 4). Plane light. 4. T-intersection in amphibole-filled vein (Sample 140-504B-197R-1, 99-101 cm, Piece 22), Plane light. 